
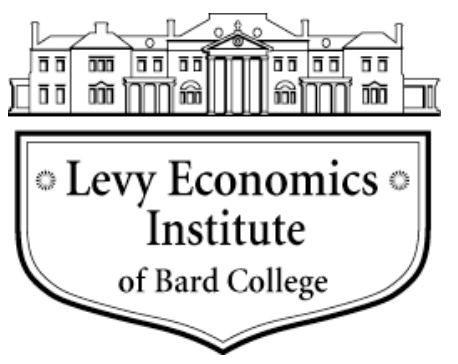

Working Paper No. 721

\title{
The Euro Debt Crisis and Germany's Euro Trilemma
}

by

\author{
Jörg Bibow \\ Levy Economics Institute of Bard College
}

May 2012

The Levy Economics Institute Working Paper Collection presents research in progress by Levy Institute scholars and conference participants. The purpose of the series is to disseminate ideas to and elicit comments from academics and professionals.

Levy Economics Institute of Bard College, founded in 1986, is a nonprofit, nonpartisan, independently funded research organization devoted to public service. Through scholarship and economic research it generates viable, effective public policy responses to important economic problems that profoundly affect the quality of life in the United States and abroad.

Levy Economics Institute

$$
\text { P.O. Box } 5000
$$

Annandale-on-Hudson, NY 12504-5000

http://www.levyinstitute.org

Copyright (C) Levy Economics Institute 2012 All rights reserved 


\begin{abstract}
This paper investigates the causes behind the euro debt crisis, particularly Germany's role in it. It is argued that the crisis is not primarily a "sovereign debt crisis" but rather a (twin) banking and balance of payments crisis. Intra-area competitiveness and current account imbalances, and the corresponding debt flows that such imbalances give rise to, are at the heart of the matter, and they ultimately go back to competitive wage deflation on Germany's part since the late 1990s. Germany broke the golden rule of a monetary union: commitment to a common inflation rate. As a result, the country faces a trilemma of its own making and must make a critical choice, since it cannot have it all — perpetual export surpluses, a no transfer / no bailout monetary union, and a "clean," independent central bank. Misdiagnosis and the wrongly prescribed medication of austerity have made the situation worse by adding a growth crisis to the potpourri of internal stresses that threaten the euro's survival. The crisis in Euroland poses a global "too big to fail" threat, and presents a moral hazard of perhaps unprecedented scale to the global community.
\end{abstract}

Keywords: Euro; Monetary Union; Banking Crisis; Balance-of-Payments Crisis; Sovereign Debt Crisis; Competitiveness Imbalances; Fiscal Transfers; Bailouts; Austerity

JEL Classifications: E42, E52, E58, E65, F36, G01 


\section{INTRODUCTION}

This paper investigates the causes behind the euro debt crisis, particularly Germany's role in it. It is argued that the crisis is not primarily a "sovereign debt crisis" and that policy prescriptions derived from this popular misdiagnosis will make the situation only worse - a (twin) banking and balance of payments crisis. Intra-area competitiveness and current account imbalances, and the corresponding debt flows such imbalances give rise to, are at the heart of the matter, and they ultimately go back to competitive wage deflation on Germany's part since the late 1990s. Germany reneged on the golden rule of a monetary union: commitment to a common inflation rate. As a result, the country faces a trilemma of its own making and must make a critical choice, since it cannot have it all-perpetual export surpluses, a no transfer / no bailout monetary union, and a "clean," independent central bank.

Starting with a comparative analysis of the budgetary and external position of Euroland in global perspective in section 2, section 3 highlights that intra-area imbalances rather than Euroland's aggregate position are at issue. As this finding implies that key institutions and policies have failed in securing the convergence and cohesion required for Economic and Monetary Union (EMU) member countries, the analysis in section 4 zooms in on the part played in all this by Germany, Euroland's core country and traditional "stability anchor." Having identified wage divergences as the critical factor, section 5 investigates how the "sick man of the euro" eventually re-emerged as Euroland's apparent powerhouse. Section 6 investigates Germany's vulnerability and highlights a critical trilemma facing the country. Section 7 warns that unconditional austerity, the supposed panacea favored by Germany, is turning Euroland into today's foremost threat to global stability and prosperity - a moral hazard challenging the global community to the utmost. Section 8 concludes and offers policy recommendations. Germany's ill-guided policies have burdened the EMU with imbalances and debt legacies that will be very difficult to overcome without reforming the EMU in the direction of a full-blown fiscal union. There is a non-negligible risk that the political process may not produce timely decisions before European Central Bank (ECB) liquidity runs dry. 


\section{EUROLAND IN GLOBAL PERSPECTIVE}

From looking at the area's aggregate situation, it is far from obvious why Euroland is today's global hotspot of instability. In particular, seen from a global perspective, Euroland's public finances do not appear to be in especially poor shape.

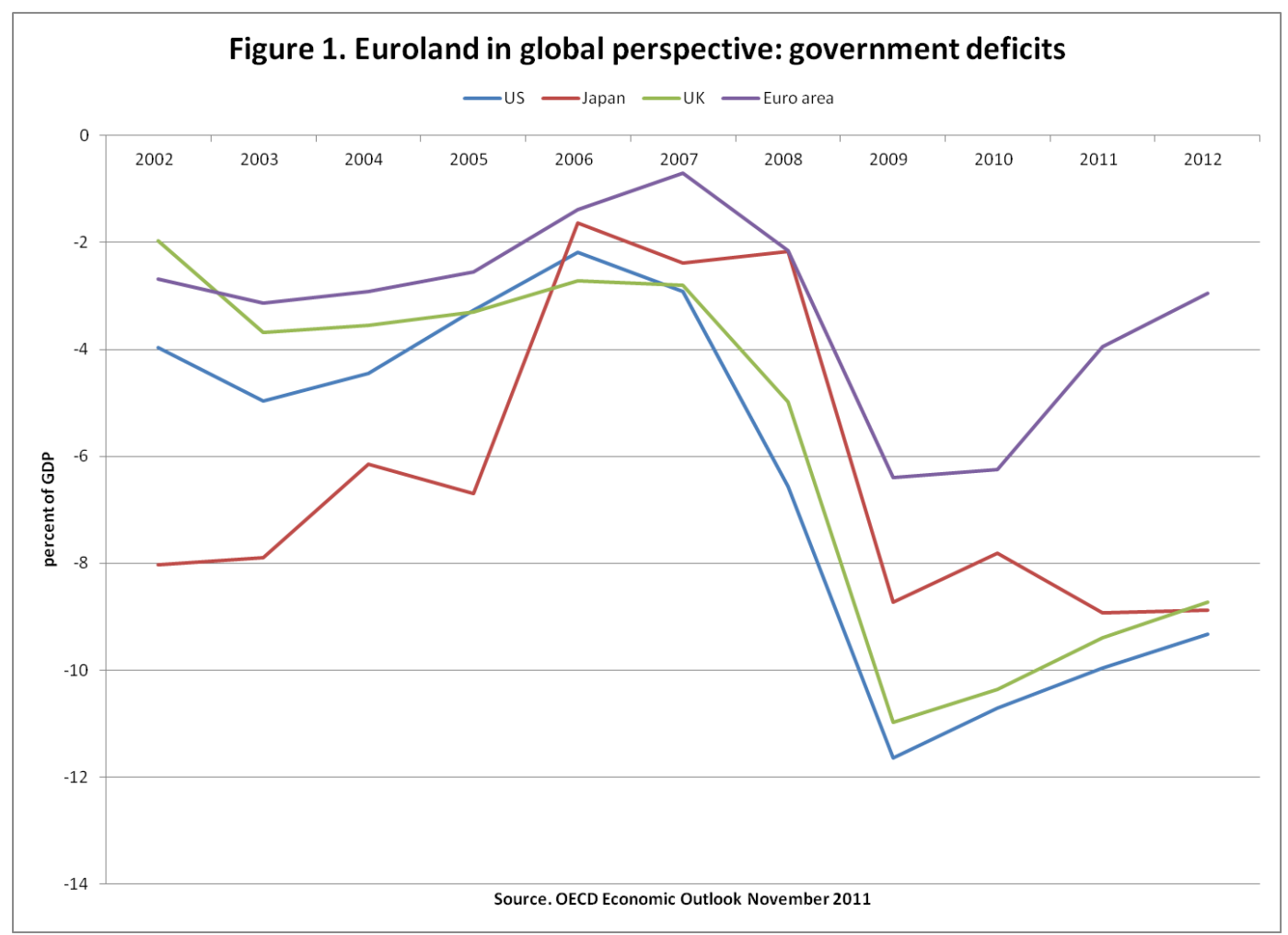

After hovering around 3 percent in the first half of the 2000s, Euroland's deficit (-toGDP) ratio briefly declined when the currency area belatedly joined the global boom in 2006-7, then deteriorated to just over 6 percent as the global crisis struck. It is forecast to decline further from its 4 percent level in 2011 to 3 percent this year. Government deficits deteriorated far more sharply in the US, UK, and Japan, with only little improvement from near 10 percent levels forecast for this year in all three cases. 


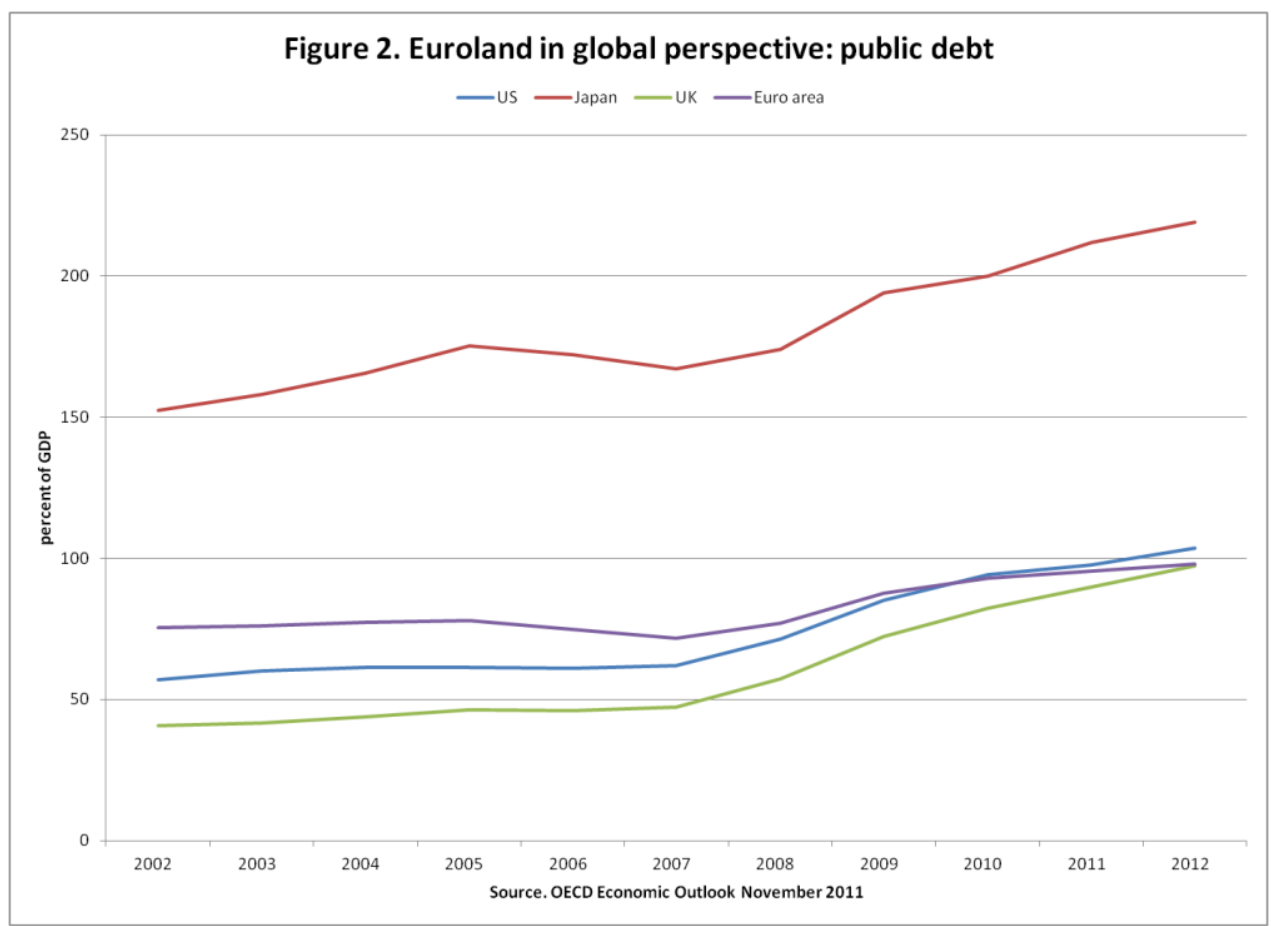

Debt (-to-GDP) ratios show a similar global constellation. While starting from a somewhat higher level of around 75 percent, the rise in Euroland's debt ratio since the global crisis has been less steep than in the other three cases. Public debt of the US, UK, and Euroland was all in the neighborhood of 100 percent of GDP by 2012, while Japan is seen in a league of its own with a debt ratio of over 200 percent.

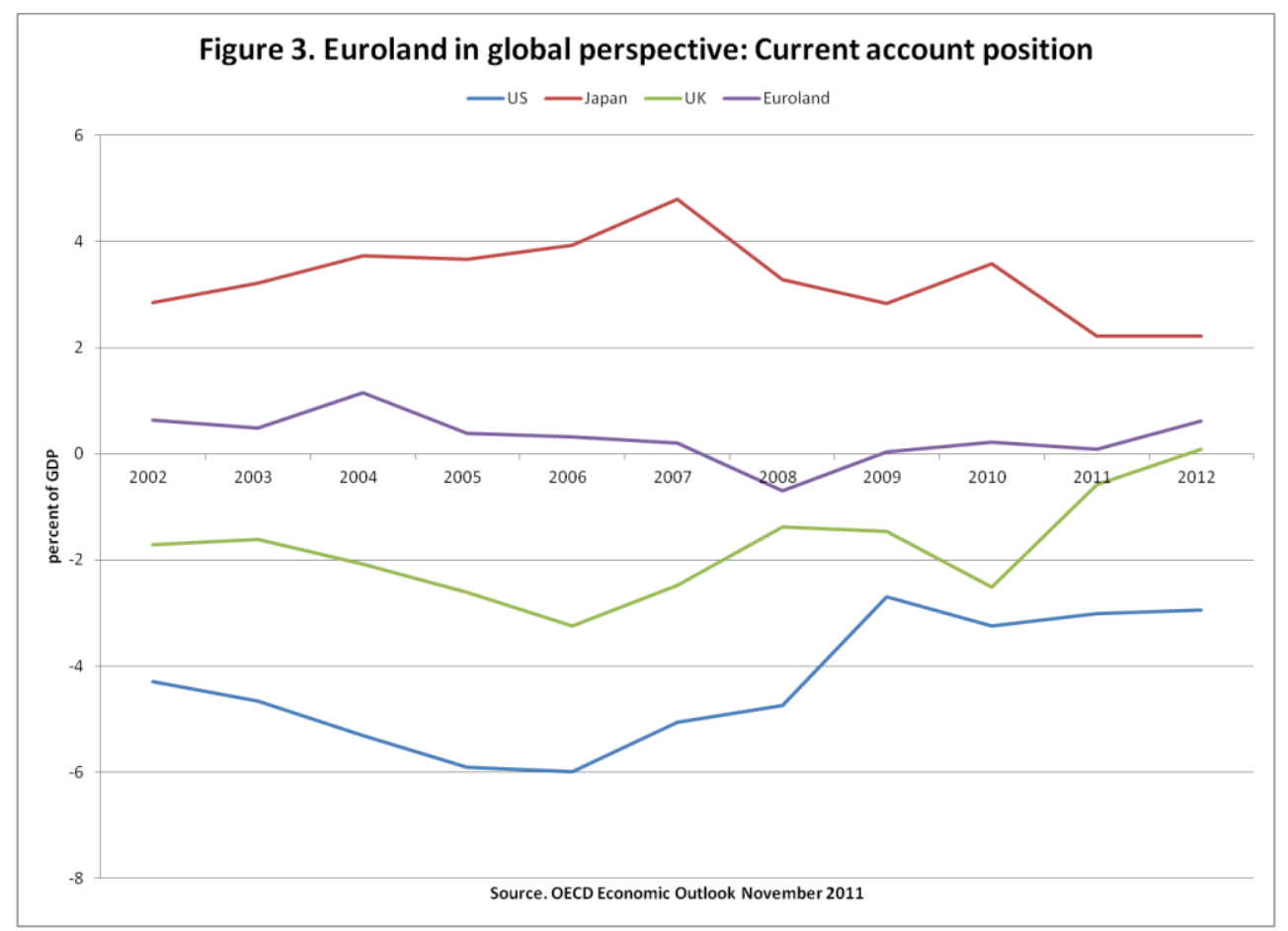


Nor does a comparison of current account positions suggest any special vulnerability in the case of Euroland. While stagnant Japan is notorious for running a large current account surplus position, both the UK and especially the US had large deficit positions prior to the global crisis. These have shrunk since then (US), or may even be on the verge of disappearing today (UK). By contrast, Euroland's current account position has been fairly balanced throughout the euro's existence, with small surpluses in most years, interrupted by small (oil-price-driven) deficits in 2000 and 2008.

This seemingly favorable comparison with other major rich countries may have encouraged complacent self-perceptions prevalent among key Euroland authorities prior to the global crisis, who often felt compelled to lecture foreign peers on their supposed failings, peddling the purportedly superior "stability-oriented" wisdom that had come to guide the design of institutions and policies in Euroland, habitually portrayed as an "island of stability" surrounded by precarious global currents. In particular, the Euroland authorities never tired of warning of the heightened risks posed by irresponsibly large "global (current account) imbalances," a malign unwinding of which they had feared Euroland might become a victim of, despite Euroland's lack of any contributing role in their buildup, in their view.

Nicely capturing the mood of European pride about being a "pole of stability for the global economy," European Union (EU) Commissioner for Economic and Monetary Affairs Joaquín Almunia (2008) blissfully declared in the foreword to the official "EMU@10” success story volume:

A full decade after Europe's leaders took the decision to launch the euro, we have good reason to be proud of our single currency. The Economic and Monetary Union [EMU] and the euro are a major success. For its member countries, EMU has anchored macroeconomic stability, and increased cross border trade, financial integration and investment. For the EU as a whole, the euro is a keystone of further economic integration and a potent symbol of our growing political unity. And for the world, the euro is a major new pillar in the international monetary system and a pole of stability for the global economy. As the euro area enlarges in the coming years, its benefits will increasingly spread to the new EU members that joined in 2004 and 2007.

While the grand "island of stability" illusion was to unravel shortly, even by the spring of 2012, the Euroland authorities are still playing catch-up with events. When, quite uncharacteristically, the International Monetary Fund urged its members to set stimulus plans in early 2008, the Euroland authorities responded that they would have none of that, arguing that it would harm the 
credibility of the Stability and Growth Pact. ${ }^{1}$ The core of Europe had entered recession in the spring of 2008, but the authorities remained in complete denial until the fall. Even the Lehman failure at first failed to awake them from their much-cherished dream that stability-oriented policies had kept the Euroland house in order, so that any storm would soon be past. Commenting on US rescue measures initiated in response to the Lehman failure, German finance minister Peer Steinbrïck declared in late September 2008 that "this crisis originated in the US and is mainly hitting the US ... [In Europe and Germany, such a package would be] neither sensible nor necessary." 2

Starting in October 2008, Euroland agreed to participate in globally coordinated stimulus measures designed to counter the global crisis, albeit never more than half-heartedly, as this was against their conviction. So when the world economy had barely turned the corner, and while the situation in Euroland, in particular, was still especially precarious, the Euroland authoritiesunder German leadership — began to pester their G-20 partners to start shifting policy focus away from stimulus and toward austerity. ${ }^{3}$ All along, the Euroland authorities maintained their selfrighteous view that Euroland had been hit as an innocent bystander by an external crisis that it had shared no responsibility in provoking, and that the rest of the world would be well-advised to follow Euroland's model of stability-oriented policymaking (see Bibow 2004, 2006a, 2007b, 2009a,b).

The facts, as they were presenting themselves to the eyes of more neutral and vigilant observers in ever greater clarity, revealed a very different picture though. Even earlier, starting in the spring of 2007, more and more signs were emerging indicating that European banks had built up large exposures to US mortgage risks that European banking supervisors seemed wholly unaware of. In so doing, European banks had provided an important helping hand in sponsoring the US housing bubble of the 2000s that was bursting at that time. In fact, the Lehman collapse, which was sending the global financial system and interbank markets, in particular, into cardiac

\footnotetext{
${ }^{1}$ See David Wessel, “Trichet: No fiscal stimulus here, please," Wall Street Journal, February 7, 2008.

${ }^{2}$ Bertrand Benoit, "Germany sees an end to U.S. hegemony," FT.com, September 26, 2008.

${ }^{3}$ Sizeable fiscal stimulus packages had been agreed upon at the G-20 summit meetings in Washington in November 2008 and in London in April 2009. Launched at the G-20 summit meeting in Pittsburgh in September 2009, the "Framework for Strong, Sustainable, and Balanced Growth" has become the centerpiece of economic policy coordination among members, committing G-20 members to "work together to assess how [their national] policies fit together, to evaluate whether they are collectively consistent with more sustainable and balanced growth, and to act as necessary to meet [our] common objectives" (G-20 2009). Turning away from their previous position that fiscal stimulus should be maintained until recovery was assured, largely under German pressure, the G20 Toronto summit in June 2010 then established fiscal consolidation as the new policy priority (Parkin 2010).
} 
arrest, made it clear that European banks had behaved especially recklessly in their gambling in foreign lands, namely by tolerating a huge short dollar position that even the ECB, as their home lender of last resort, would be unable to look after (at least without the cooperation of the US Federal Reserve, met through currency swap arrangements between the central banks in due course - see Baba, McCauley, and Ramaswamy 2009; McCauley and von Peter 2009; McGuire and von Peter 2009; Borio and Disyatat 2011).

Reckless global adventures of European banks and the buildup of corresponding global exposures meant that Europe was about to have a major banking crisis on hand. In this way, the US "subprime mortgage crisis," as it was initially called, was not much of an "external” shock at all, but an internal credit shock from the beginning. Alas, on top of stress due to foreign exposures, property market bubbles closer to home started bursting very much in tandem with events across the Atlantic. In this regard, the ECB's tightening binge initiated in late 2005 had surely played its part in the anything-but-preemptive bubble "popping" that was going to require a lot of "mopping up" at the home front, too (much to the disappointment of ECB propaganda on this count — see ECB 2005 and Bibow 2005, for instance).

Together, these events - and the unfolding banking crisis they heralded-were going to undermine the continuation of lush intra-area capital flows that severely unbalanced demand growth in Euroland had come to depend upon. As will be developed in detail below, Europe's banking crisis is inherently intertwined with an intra-EMU balance of payments crisis.

However, in the minds of the Euroland authorities, the illusion of Euroland as an innocent bystander that got hit by a US-made external crisis survived the Lehman failure for another year, when it finally gave way to a fresh illusion, equally cherished until this day, namely that Euroland has fallen victim to a "sovereign debt crisis." Starting in late 2009, events in Greece, a mere fortieth part of the Euroland economy, came to epitomize the evil powers of fiscal profligacy and were quickly identified as the alleged root cause of all euro troubles. ${ }^{4}$ Debunking this new myth will require taking a closer look inside Euroland.

\footnotetext{
${ }^{4}$ Earlier in 2009, well before Greece moved into the spotlight, market stress following a series of rating downgrades of Ireland had prompted Germany's finance minister Peer Steinbrück to declare: “the euro-region treaties don't foresee any help for insolvent countries, but in reality the other states would have to rescue those running into difficulty" (Benoit 2009).
} 


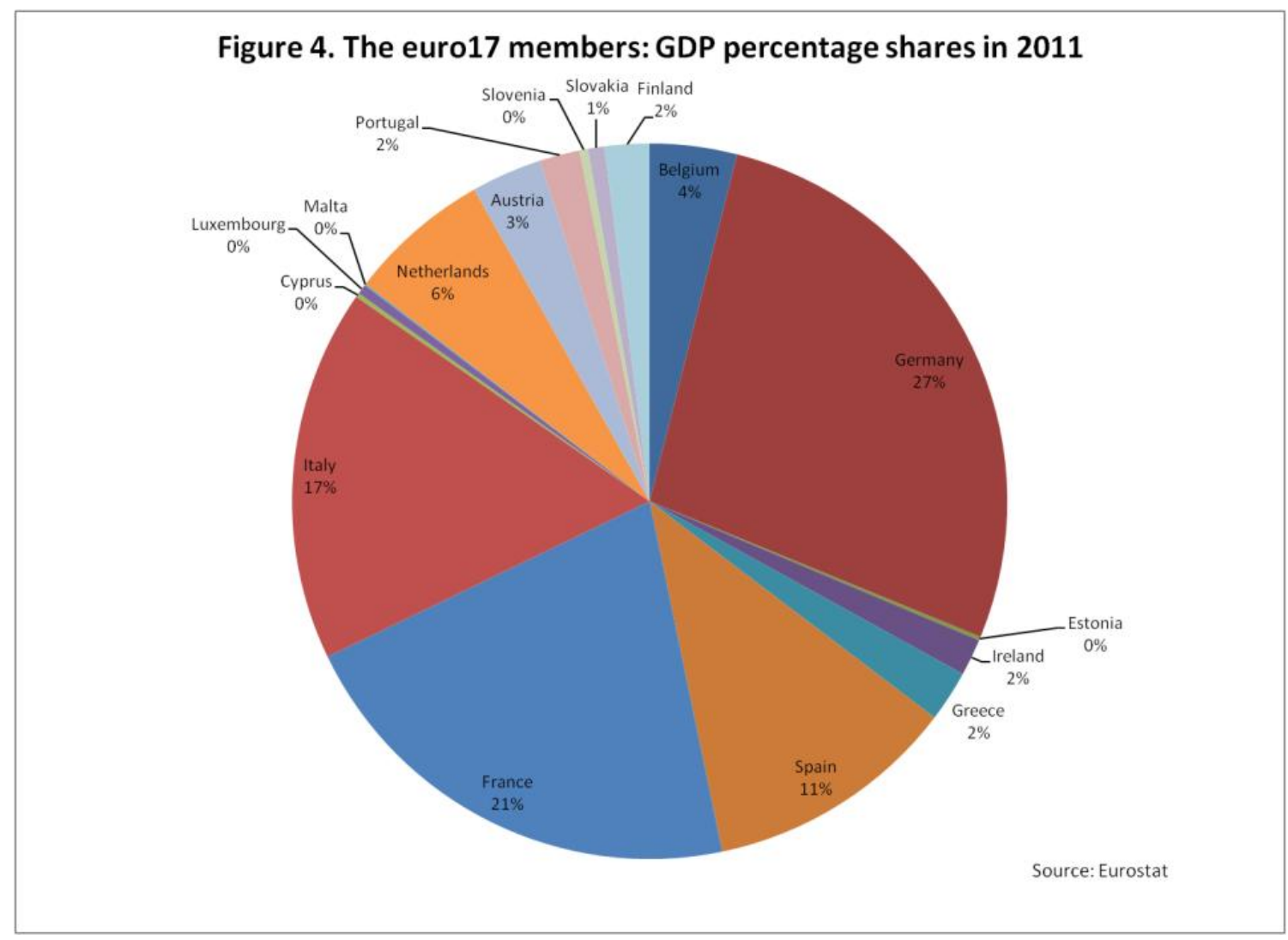

\section{A LOOK INSIDE EUROLAND: ILLUSION OF STABILITY, AND NOT MUCH UNITY AT ALL}

The Maastricht regime of EMU is designed for stability - to satisfy and export German "stability

culture." Stability is believed to come about through the ECB's (price-) stability(-only)-oriented monetary policy of keeping inflation "below but close to 2 percent" paired with "sound" public finances, that is, budget deficits below 3 percent (and balanced or in surplus over the course of the cycle as prescribed by the so-called "Stability and Growth Pact"-SGP). When Euroland became home of acute debt market disruptions in 2010, ECB representatives were quick to point out that independent central bankers had dutifully delivered on their part of the deal: with an average inflation rate of 1.99 percent between 1999 and 2011, the masters of Europe's monetary union were surely faultless (Trichet 2011). It was the economic union part of the "EMU" that had failed, and a look at budget deficits made it seemingly obvious to identify finance ministers as the villains in the play. 


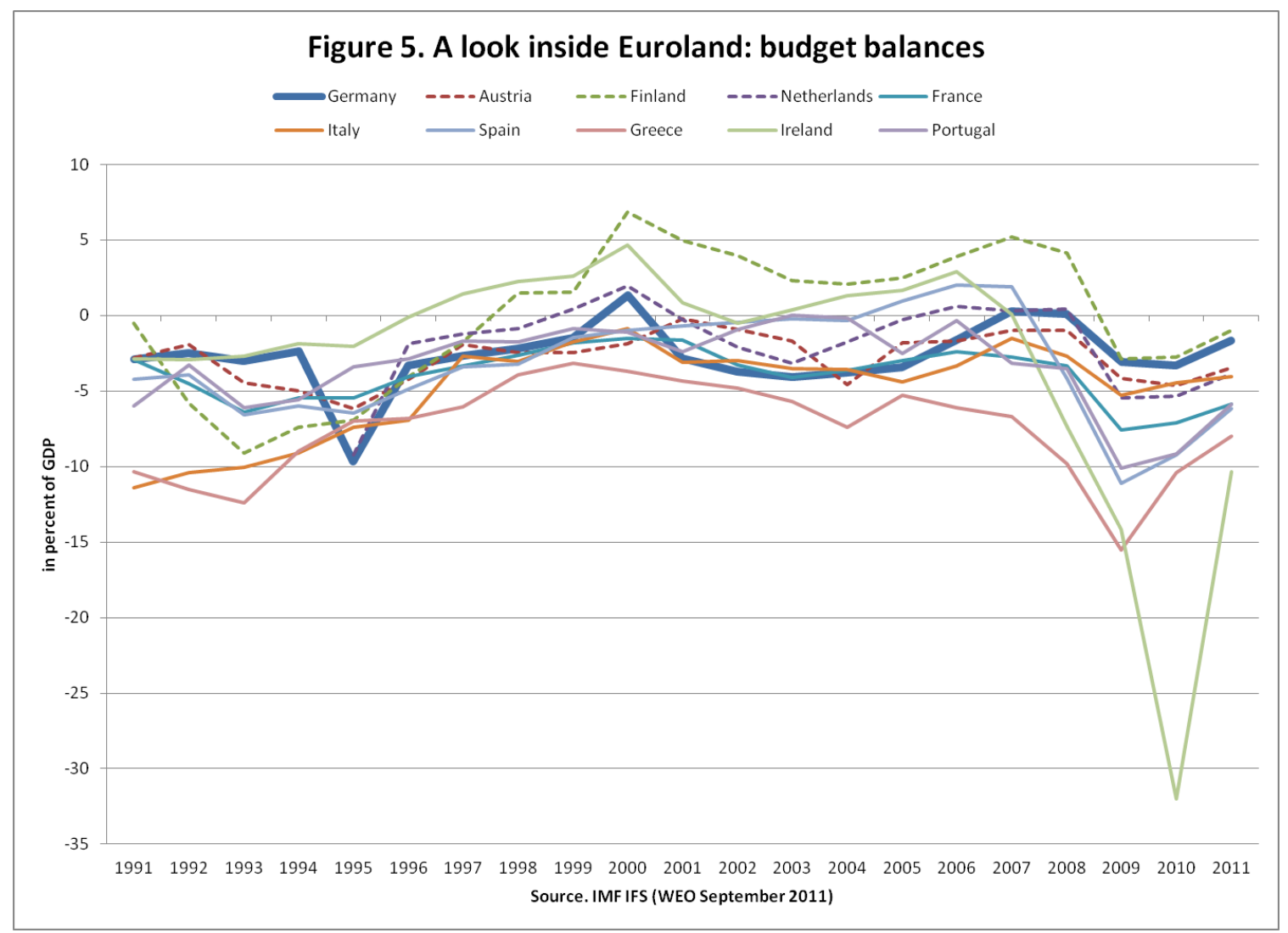

In particular, for long fudging its budgetary numbers, Greece had run budget deficits that were persistently above the 3 percent mark both before and since joining Euroland. When a new incoming government brought this matter to daylight in the fall of 2009, yields on Greek government bonds surged, effectively shutting off the Greek government's access to market funding in due course. With fiscal misdoings on the part of Greek profligates easily identified as the cause of Greek troubles, old German fears that had inspired the "no bailout" clause of the Maastricht Treaty and the later SGP were seemingly verified in 2010, as the "sovereign debt crisis" spread across Euroland and beyond.

A number of observations are in order here about the rather diverse budgetary situation that has characterized Euroland both prior to and since the global crisis of 2008-9. First, Greece clearly is an outlier. While other member's fiscal balances primarily reflect distinct cyclical patterns, control of public finances in Greece does appear to have been a matter of some neglect. Second, running large budget surpluses since the euro's launch, Finland is the opposite outlier. It is noteworthy that only a decade earlier, Finland had found itself in a similar fiscal situation as Greece is in today. The turnaround in Finland's fiscal fortunes involved a large depreciation of the Finnish markka against the deutschmark of 50 percent between 1991 and 1993 (only half of 
which was recovered by 1999) that restored the country's competitiveness and, together with a refocusing of its trade away from the collapsed Soviet Union, paved the way for large current account surpluses.

Third, in running both favorable budgetary and external positions, Finland is aligned with Austria, the Netherlands, and Germany today. Fourth, however, among the group of the fiscally virtuous, Germany actually had budget deficits of around 3 percent of GDP for most of the time since 1991. Prior to its current favorable position, Germany's budget turned into balance only briefly and on two occasions: at the peak of the dot.com boom in 2000, and again at the peak of the global boom of the 2000 s.

Fifth, the opposite group of the fiscally challenged includes two countries that actually ran budget surpluses prior to the crisis: Ireland and Spain. These two countries then saw the sharpest deterioration in their fiscal balances as crisis struck. Sixth, while Portugal's budgetary deterioration was less drastic, the country's current predicament in terms of required austerity is in the same order of magnitude as that of Spain; although its economic weight in Euroland is much smaller. Finally, France, the number 2 member in terms of size, is currently in deeper fiscal doldrums than Italy, Euroland's number 3; which has a more tarnished fiscal reputation and is considered part of the extended "PIIGS" group (Portugal, Ireland, Italy, Greece, and Spain).

Turning to debt ratios, the steepest and largest (percentage-point) rises have occurred in Ireland, Greece, Portugal, and Spain. While Greece is again the outlier (or frontrunner?) at the high end of the spectrum, Ireland has suffered the greatest crisis impact by far, moving from top performer to among the three worst. While starting out from a much higher level, the rise in Italy's debt ratio has been more moderate and comparable to the other countries. Perhaps the most noteworthy trend of all is the almost synchronous doubling in the debt ratios of both Germany and France, from 40 percent to over 80 percent, since 1991—when fiscal consolidation was promoted to the highest ranking economic policy priority, becoming the embodiment of the Maastricht wisdom of economic policymaking. 


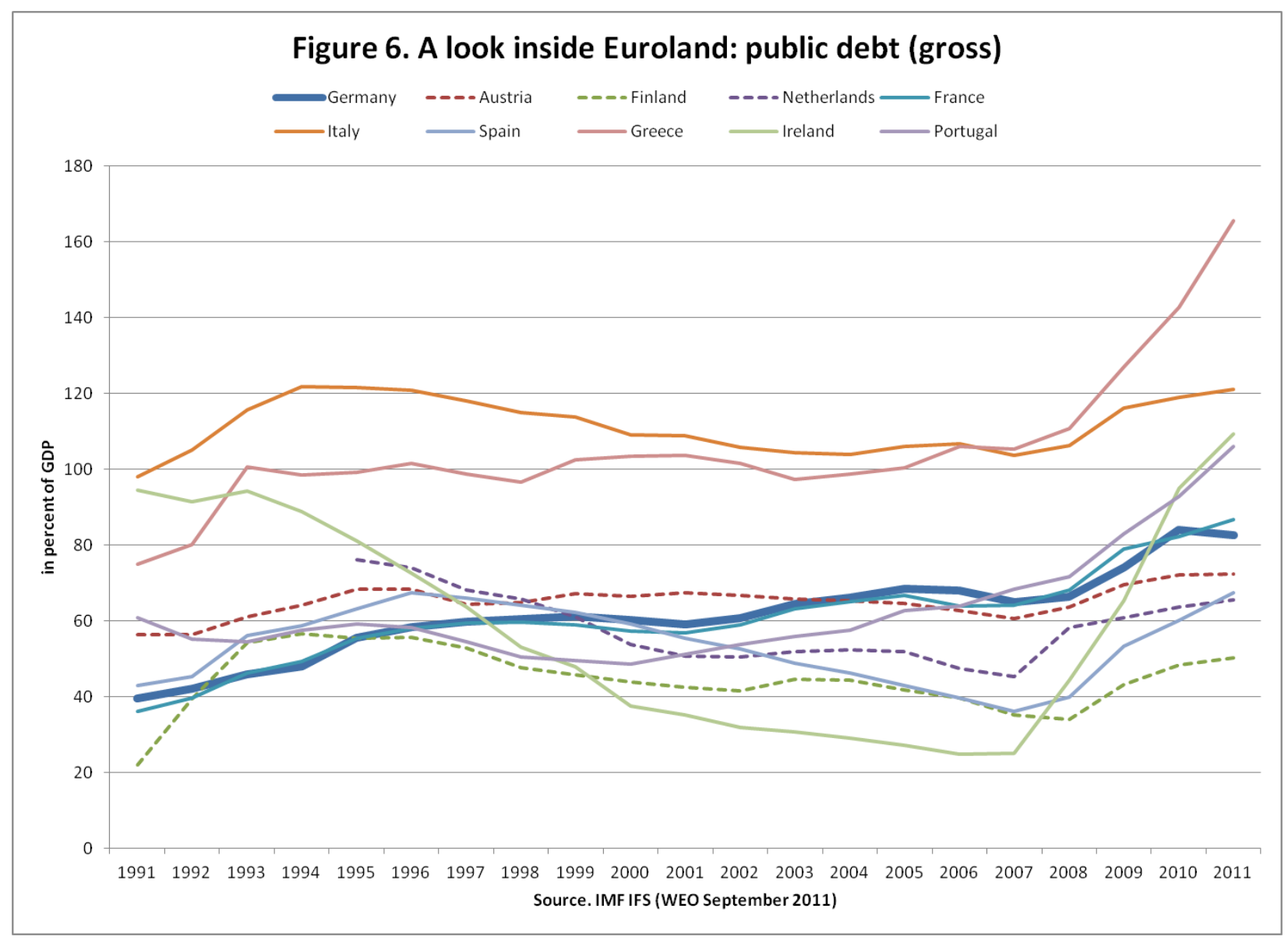

I observed above that the fiscally vituous EMU members also share another common feature: current account surplus positions. While Euroland's overall current account positon has been roughly in balance throughout, the fiscally challenged EMU members are all to be found on the side of current account deficit positions. This finding is not a mere coincidence.

As Wolf (2012) recently observed that "the eurozone is at war with double-entry bookkeeping," a quick refresher in national income accounting may be in order here. National income accounting for a closed economy informs us with irrefutable certainty that the public sector of any one country can only run a budget surplus, that is, spend less than its income, if the private sector does the opposite, that is, spends more than its aggregate sectoral income. Private sector "overspending" may either be driven by the business sector (the dot.com investment boom being an example) or by households (typically, housing booms), or both. By contrast, if the private sector should embark on a sharp retrenchment, as was the case in the global crisis of 2008-9, the public sector balance will inevitably be the mirror image, with revenues falling and expenditures rising, reflecting the working of the "automatic (fiscal) stabilizers." In open 
economies, an external sector needs to be added to the set of accounts and sectoral balances, as captured by the balance of payments on current account. By logical necessity, any particular country can only succeed in running a public sector surplus if either its own private sector and/or the foreign sector "overspend."

In the Euroland context, Spain and Ireland provide examples of the former, propelled by property market booms that not only allowed for national public sector budget surpluses, but for current account deficits on top of that; with private sector bubble hangovers today being all the worse for that. Germany, Austria, Finland, and the Netherlands provide examples of the latter: countries that relied on current account surpluses to help consolidate their own public finances. Being at war with double-entry bookeeping, these countries may even convince themselves of their own virtuousness, but their success was actually only made possible by others' "sinfullness." As to the aim of the SGP, except by courtesy of the rest of the world, Euroland as a whole can actually only achieve a balanced public sector position if its private sector stops saving in the aggregate.

These remarks should not only warn us of Euroland's ill-guided obsession with the Greek outlier, sponsoring the convenient illusion of a "sovereign debt crisis." More generally, an exclusive focus on public sector deficits only also runs the risk of seriously misdiagnosing private sector debt fragilities.

For at the heart of today's euro debt crisis is an intra-area balance of payments crisis caused by seriously unbalanced intra-area competitiveness positions and the - largely privateaccompanying cross-border debt flows. This issue is the subject of the next section. Suffice to mention that the future performance of Euroland will not so much depend on small members, such as Austria, Finland, and the Netherlands, running current account surpluses, nor on other small members, such as Greece, Ireland, and Portugal, running current account deficits. The real issue is the huge (almost 10-percentage-point!) shift in Germany's current account position after 2000, and the opposite shifts that have occurred in the other larger member countries. While Spain, number 4 in size, has shrunk its current account deficit through austerity-driven income compression much in line with the smaller PIIGS, the coming adjustment in Italy and France is bound to add enormous spin to Euroland's ongoing debt deflation process. 


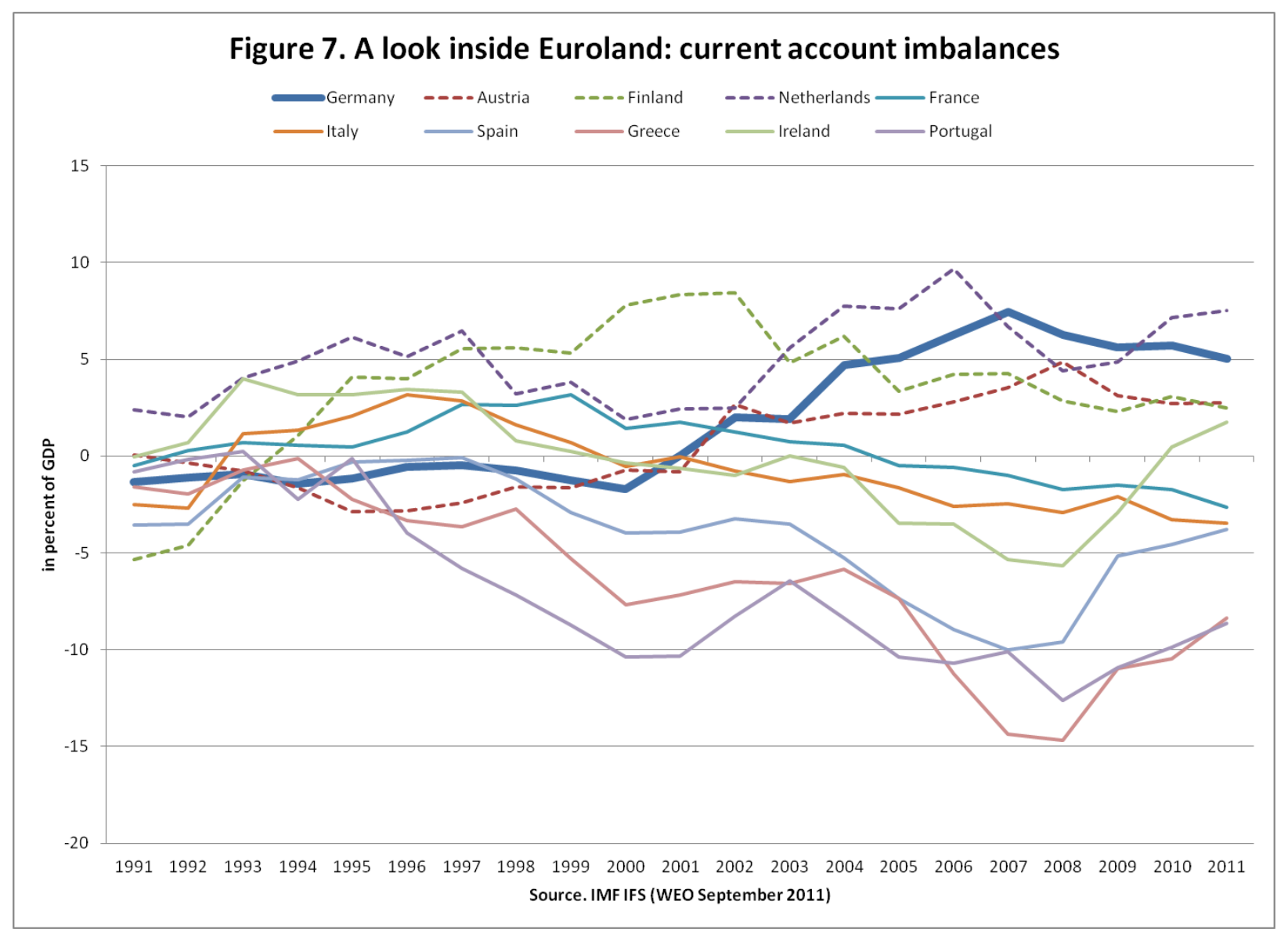

\section{ORIGINS OF DIVERGENCES AND BUILDUP OF INTRA-AREA IMBALANCES}

Current account imbalances can arise for a number of reasons. The following two were the most relevant in the Euroland context: first, competitiveness positions running out of kilter; and, second, divergent domestic demand growth rates. Closely intertwined, these two influences actually reinforced each other owing to the working of the Maastricht regime.

In general, the evolution of competitiveness at the national level is mainly shaped by two factors: first, the rate of increase in wages (and other costs) relative to the rate of productivity growth; and, second, the exchange rate. As Euroland has eliminated the exchange rate factor, completing the long-term zeal of getting rid of the risk of beggar-thy-neighbor policies through competitive exchange rate devaluation, only the former factor remains relevant-attaining paramount importance in maintaining internal balance!

Keynes had identified aggregate wage trends, interacting with national monetary policies, as shaping countries' competitiveness and net export performance in The General Theory. The 
vital importance of - relative - national wage and productivity trends inside a monetary union can be most easily understood in terms of Mundell's (1961) seminal contribution to "optimum currency area" (OCA) theory, focusing on "asymmetric shocks" and how either market mechanisms and/or policy responses might help to rebalance economies. Consider a shift in demand favoring German over French cars, leading to out-of-sync cyclical positions and trade imbalances between the two countries subjected to the asymmetric shock. An easy way to counter the shock involves exchange rate realignment. If this is not an option, and in a currency union it isn't, the same outcome could be achieved through wage-price flexibility, with an "internal devaluation" in France, and/or the opposite in Germany. Doubting that wage-price flexibility would be sufficient as a substitute for exchange rate adjustment, Mundell concluded that countries (using Canada and the US as examples) would have to rest their hopes on factor mobility as an alternative adjustment mechanism instead. Importantly, any of the considered market or policy adjustments would only become necessary in the presence of asymmetric shocks, shocks that hit countries differently and hence unbalance the currency union.

Arguably, the most important implication of Mundell's analysis is the need for common wage bargaining - or some form of area-wide coordination - so as to prevent national wage trends from becoming the source of asymmetric shocks.

Europe had learned its lessons from the 1930s competitive currency devaluations. From the beginnings of European integration, it was emphasized that exchange rates were a "matter of common concern," and the euro provided the "coronation" in handling this very threat. Unfortunately, the issue then somehow fell through the cracks, probably owing to Europe's blind obsession with structural reform of labor markets, that the euro would make national wage trends all the more important, and, most fundamentally, very much a "matter of common concern" indeed.

As a rule, if wages and productivity grow at the same rate, "unit-labor costs" stay steady; and so would external competitiveness of countries that have the same growth rate in unit-labor costs (assuming that profit margins and indirect taxes, etc. remain unchanged, too). As unit-labor costs are the foremost determinant of inflation (beyond the very short run of any temporary influences), the target for the rate of inflation chosen by the authorities for any particular country (or group of countries) thereby also provides the standard or norm for the growth rate of nominal unit labor costs. Essentially, a monetary union is a commitment to a common inflation rate. 
Europe's EMU meant a commitment of member countries to a common inflation rate that is also very low and guarded by an - untouchable - independent central bank. The guardianship of the euro by an independent central bank was a German sine qua non for giving up the country's beloved deutschmark.

Germany thoroughly misunderstood its own historical record, though, and how monetary union would change its own position. Ironically, it was Germany, of all countries, that came to depart from its own historical stability norm under the Maastricht regime-with potentially fatal consequences for the euro. According to OCA theory, common wage bargaining — or wage coordination - is critical in preventing asymmetric shocks and sustaining a monetary union.

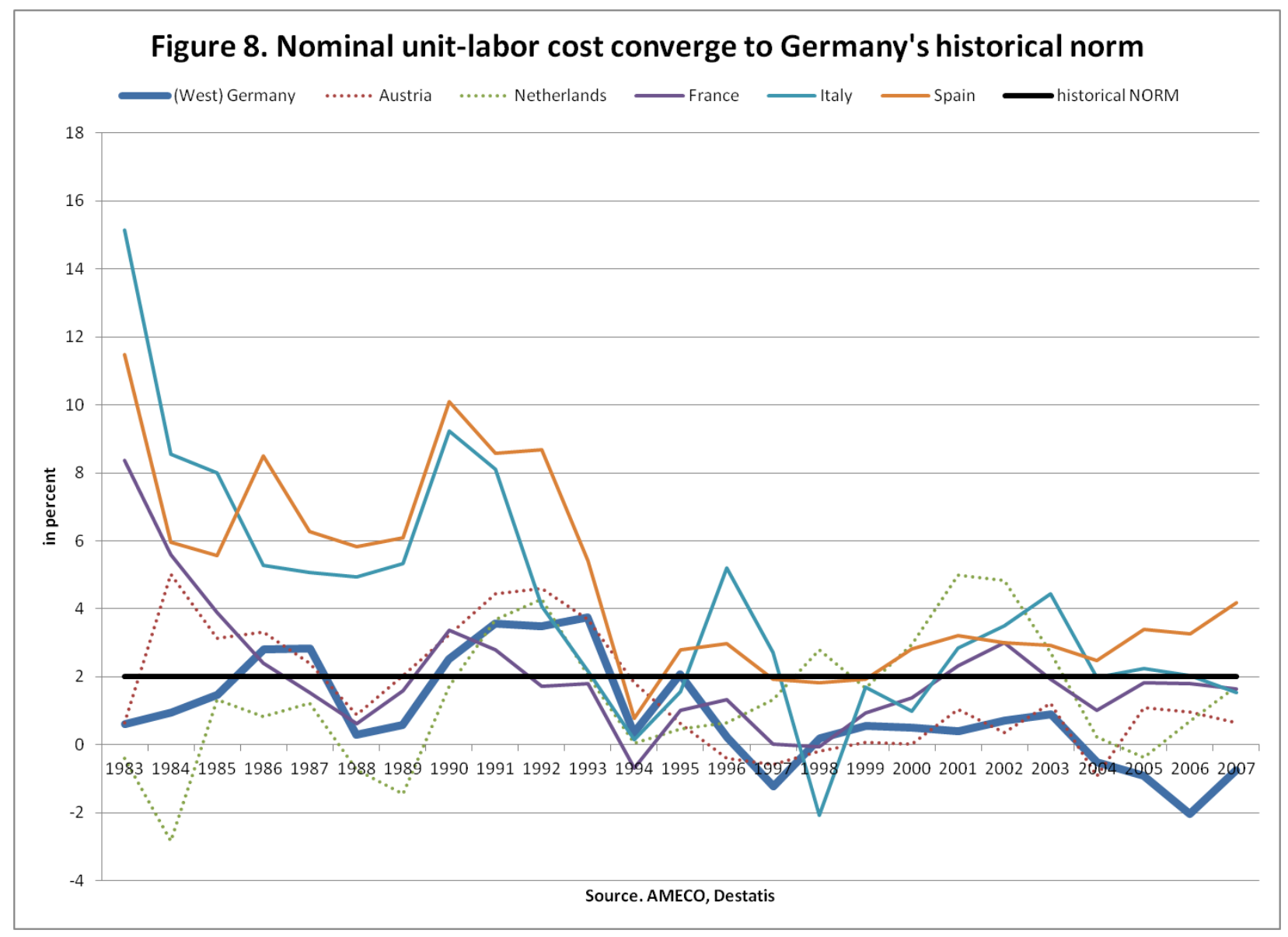

The ECB defined price stability as an area-wide harmonized index of consumer prices (HICP) inflation rate of "below but close to" 2 percent. In the absence of any asymmetric shocks that require adjustment in relative competitiveness positions, this implies that national unit labor cost trends should converge to 2 percent. Convergence to a common 2 percent trend would be in 
line with monetary union members' commitment to a uniform inflation rate, as well as with the older commitment, predating monetary union, of non-recourse to competitive devaluation strategies. In the 1980s, large disparities in unit labor cost growth rates still prevailed.

Historically, Austria and the Netherlands were most closely aligned with trends in Germany. In the 1980s, the Netherlands actually systematically underbid Germany (Bibow 2001)—providing it with some scope for slippage later on. While France converged to the German standard by the mid-1980s, Italy and Spain took until the early 1990s. At the start of the euro, Euroland had fully converged to the historical German norm of 2 percent and, by and large, has stayed close to that norm ever since - except for Germany itself, that is. For, starting by 1996, Germany shifted a gear down and henceforth established its own new lower norm of zero nominal unit labor cost inflation.

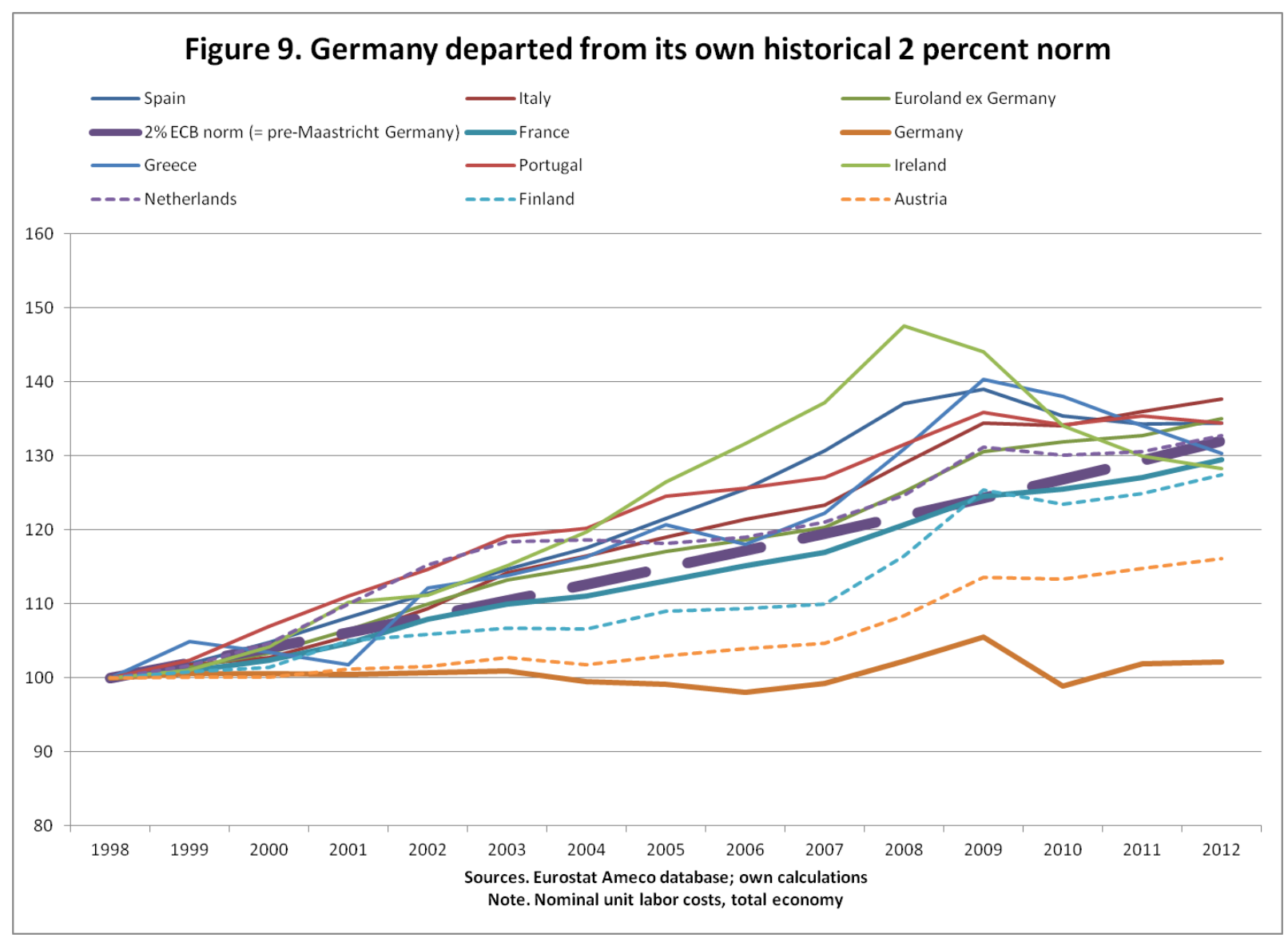

Importantly, the decline in unit labor cost growth was not due to any acceleration in productivity growth, but caused by a marked decline in wage inflation. In other words, not German engineering ingenuity, but wage restraint gave German exporters an extra boost. 
German productivity growth since 1998 was no more than average, similar to that of France and Portugal, well below that of Greece and Ireland as the outperformers; while Italy and Spain stand out as the productivity growth laggards.

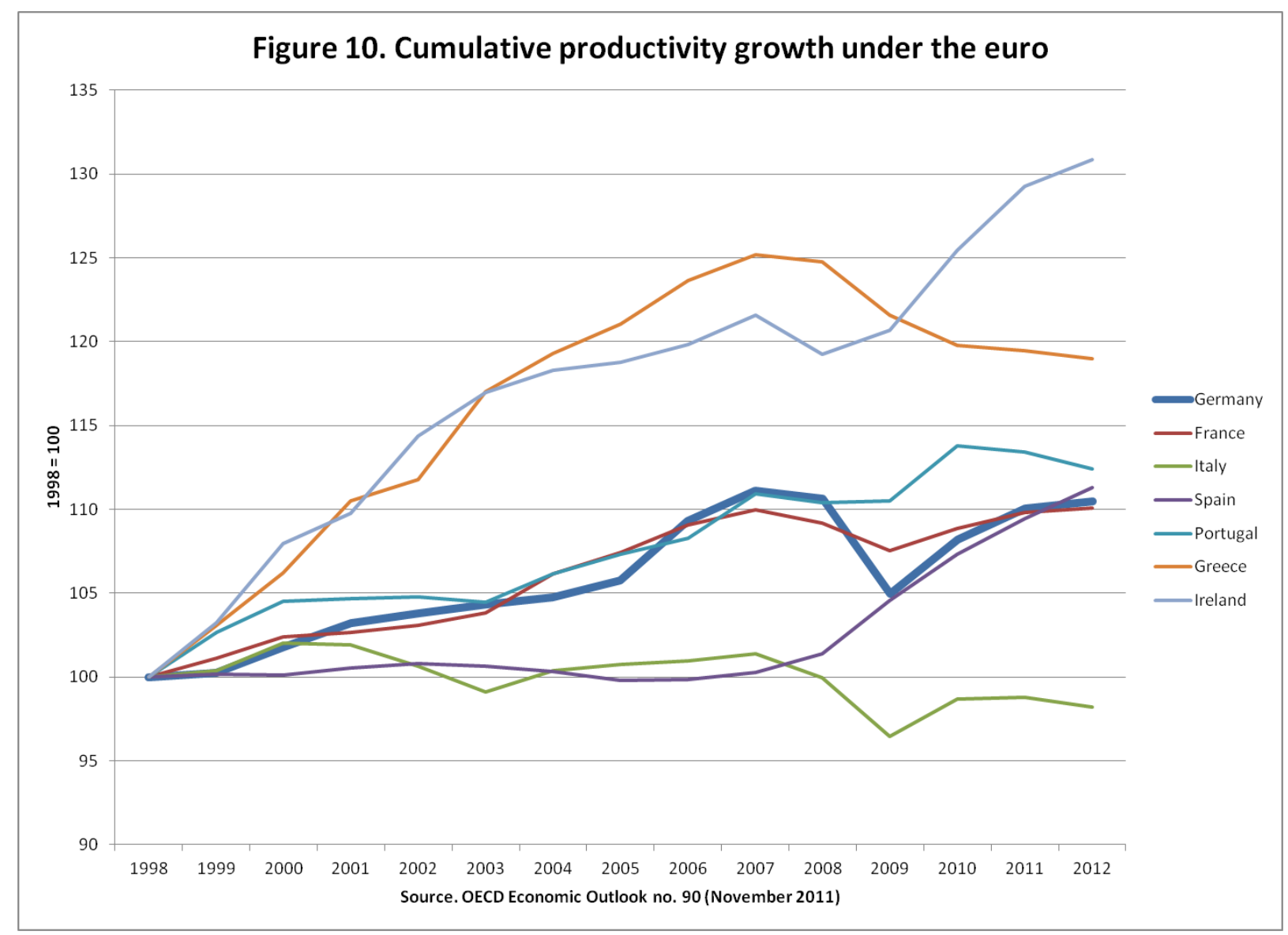

With wage repression as the true cause of Germany's competitieness gains inside Euroland, the point is that, just like inflation differentials, unit labor costs growth differentials are cumulative. If sustained over a number of years, divergent trends build up to ever larger distortions in relative competitiveness positions (Bibow 2006b; Flassbeck 2007). 


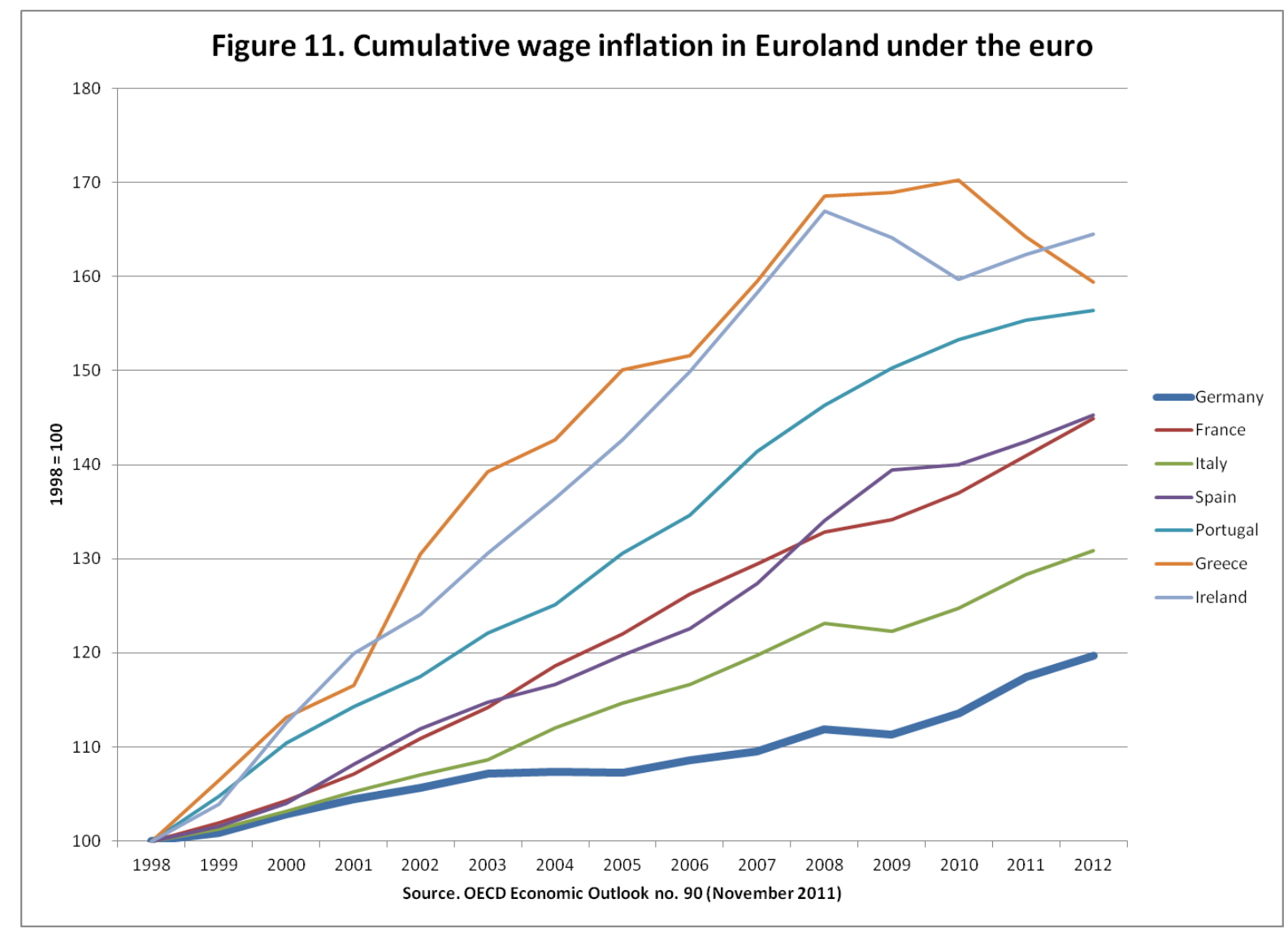

Not Germany but France most loyally stuck to the EMU commitment to a common 2 percent inflation rate throughout the euro era. Of the other partners, Italy erred somewhat in the upward direction, and even more so Spain and the smaller of the PIIGS countries. On the other hand, of the smaller current account surplus countries, Austria — and to a small extent Finland, too-stayed persistently below the stability norm. But of all partner countries, it is Germanythe old stability anchor of the Exchange Rate Mechanism of the European Monetary Systemwho stands out as the true outlier of the whole pack.

There can be no serious doubt that Germany's departure from its own historical stability norm provided the main cause behind the build-up of intra-area current account imbalances. The next section will investigate how the Maastricht regime further amplified divergences driven by unbalanced wage trends.

Going forward, what is most important is that, while the PIIGS have meanwhile converged back toward the price level (or unit labor cost) path originally committed to, a huge competitiveness gap remains between Germany and the rest. This vital challenge to the euro's survival will be taken up again in section 8 below. 


\section{REAWAKENING OF THE "SICK MAN OF THE EURO": A "MADE IN GERMANY" ECONOMIC MIRACLE}

In the spring of 1998, Germany barely met the 3-percent deficit hurdle that, by the rules of the Maastricht Treaty, was so critical in getting the euro off the ground by 1999. Starting from a balanced budget in 1989, the initial budgetary impact of German unification —which essentially bankrupted much of the East German economy over night-was a deficit of 2.8 percent in 1991. Owing to the authorities' thoroughly ill-guided macroeconomic policy response to the unification challenge, the West German economy, too (and much of the rest of Europe) was then recklessly pushed into recession in 1992-93 (Bibow 2003).

The labor market and budgetary consequences of the latter policy mistake were to shape the country's economic policies until the global financial crisis in 2008-09-while unconditional fiscal consolidation was made one never-to-be-questioned pillar of German policymaking and wage restraint the other. A severely unbalanced economy, persistently high unemployment, and continued budgetary stress were the predictable fallout of a policy wisdom that notoriously ignores domestic demand management.

Apart from two brief interruptions in 2000 and 2007, when export-driven booms temporarily balanced Germany's public budget, the country's finance ministers found themselves engaged in a Quixotic fight with the Maastricht 3-percent ceiling, choking growth through austerity measures and wage restraint, and watching the deficit refusing to decline as a result. Germany was among the first countries to breech the SGP's magic number in the early 2000s, famously dodging Brussels' excessive deficit procedure by colluding with France on the matter. At that time, Germany even became known as "the sick man of the euro." 


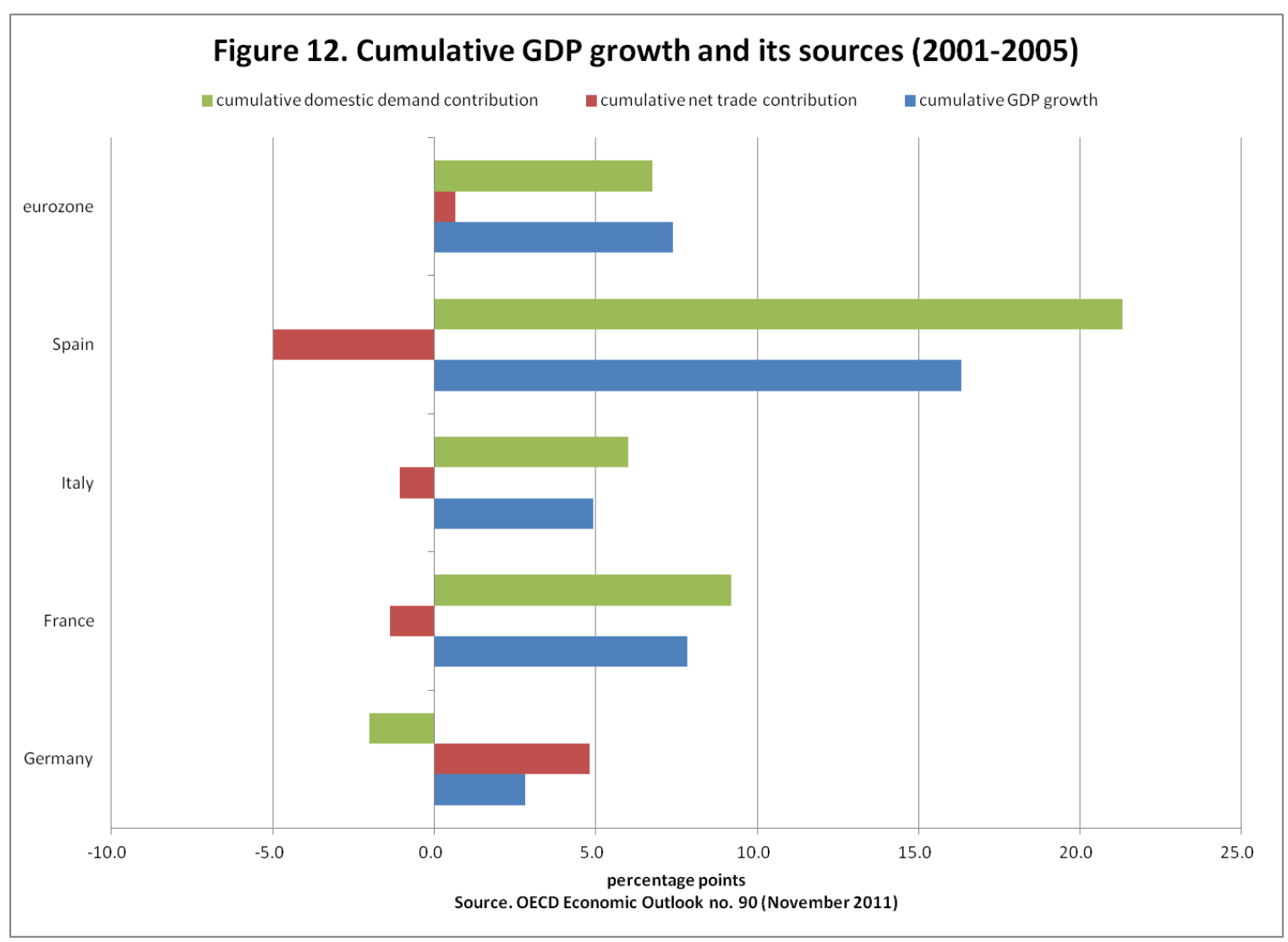

This uncomplimentary title was bestowed upon Germany for good reason. It was not only a reflection of the fact that the country's overall GDP growth was very meager indeed. In the period 2001-2005, Germany literally managed to grow (rather, crawl) on one cylinder only: (net) exports. Even when domestic demand finally got ignited at the peak of the global boom in 200607, this mainly owed to export-induced investment, while private consumption remained extraordinarily weak throughout. With domestic demand persistently "sick," thanks to unconditional austerity and wage restraint, exports were Germany's lifeline and sole —albeit cyclical — engine of growth. Protracted stagnation in Germany meant a correspondingly easier "one-size-fits-all” ECB stance for Euroland, far too easy for the periphery, where bubbles were nourished as a result.

Note then how the Maastricht regime actually amplified the asymmetric shock that arose as Euroland failed to ensure common wage bargaining. In essence, once Germany's national wage trend diverged from the Maastricht stability norm, negative feedback loops owing to regime-inherent forces made the partners drift apart ever farther. In particular, as Germany embarked on relative wage disinflation, this meant the ECB's “one-size-fits-all” monetary stance became relatively tighter for Germany than in countries with higher wage and price inflation, 
dampening credit growth and asset prices in line with wage deflation. Further headwinds arose as the stagnant economy triggered a budgetary squeeze in compliance with the SGP, as the deficit ratio exceeded 3 percent between 2002 and 2005. Countries with higher national wage trends would experience the opposite kind of regime-inherent forces at work, even more so as stronger growth performances makes wages diverge from the norm in the upward direction. ${ }^{5}$

While balancing Euroland's external competitiveness is largely dependent upon the euro exchange rate, internally, balancing EMU partners' competitiveness positions has to run through unit labor costs. While Euroland's aggregate current account position may be roughly balanced or not, in principle, individual countries' intra-area and extra-area current account positions may reveal diverse patterns depending on their respective trade orientations. The focus in the following is on Germany.

Traditionally, three-quarters of German exports are headed for European destinations. In the 1990s, European Union members received roughly two-thirds and Euroland members just under half of German exports. Since 2008, the shares of Germany's traditional export markets have shown declining trends, while the share of non-European export destinations has been on the rise, reaching 30 percent by early 2012. The ongoing shift in shares of German export destinations is foremost a reflection of Europe being the outstanding laggard in the unbalanced global recovery from the 2008-9 crisis (UNCTAD 2010).

\footnotetext{
${ }^{5}$ In May 2005, Otmar Issing, the ECB's first chief economist (and, having previously served that same role at the Bundesbank, mastermind behind the ECB's approach to "stability-oriented" monetary policy) declared, in reflecting back on his credo that "one size must fit all" made at the start of EMU: "Today, in light of the evidence gathered so far in the euro area, I am more confident in saying: 'One size does fit all!'” (Issing 2005). In 2005-6, this author raised alarm about intra-area divergences and imbalances at numerous European conferences, including one in Brussels at which European Commission and ECB representatives were present. See Bibow (2006b, 2007a).
} 


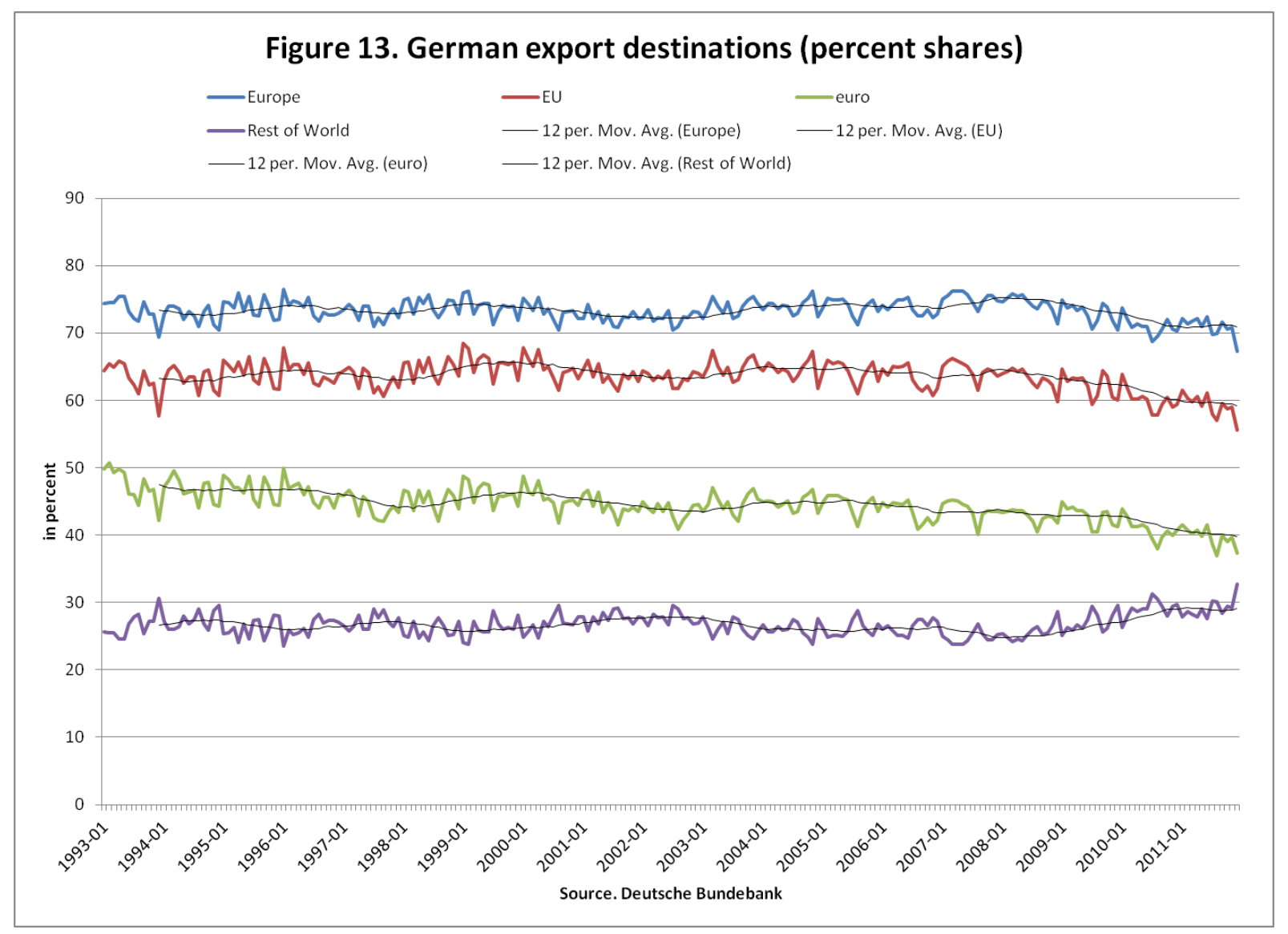

A look at the composition-by-destination of Germany's trade surpluses is most revealing, as these are even more regionally concentrated in Europe. Moreover, trade surpluses with the EU and Euroland as shares of Germany's overall surplus position were rising from the early 2000s until the crisis, as euro appreciation initially made German exports less competitive internationally while Germany was gradually gaining ground vis-à-vis its European partners, with trends peaking at shares of over 80 percent and two-thirds, respectively. In the context of the ongoing crisis in Europe, these trends have reversed, with booming German exports to China and other fast-growing emerging market economies partly offsetting the spreading gloom in Germany's traditional European export markets. Within Euroland, exports to and export surpluses vis-à-vis France were still growing in early 2012, while the crunch in the southern periphery had started hitting back on German exports earlier already. 


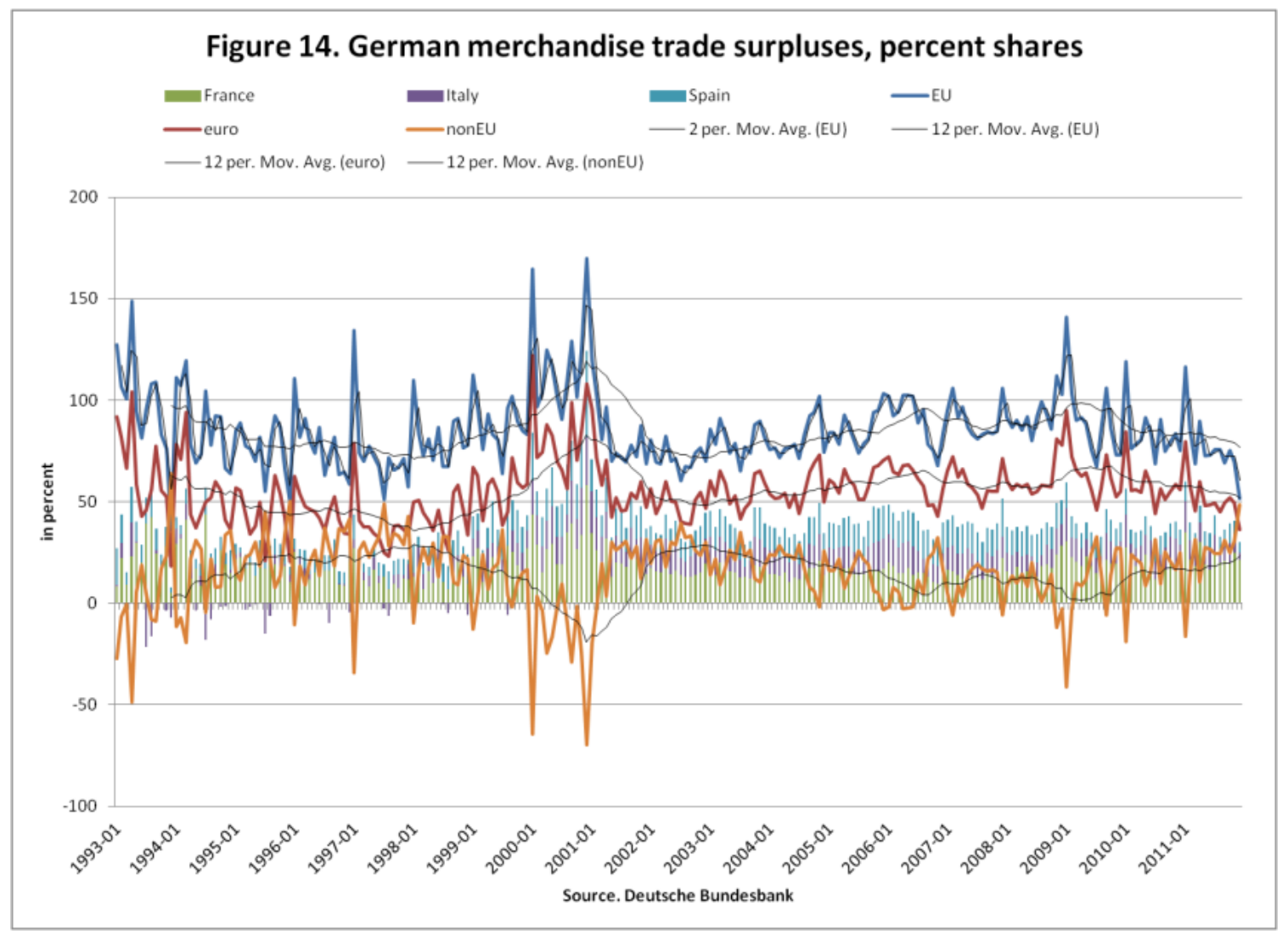

Suffice to mention that while merchandise trade surpluses dominate Germany's current account position vis-à-vis Euroland, wage restraint has also contributed to reversing the previous trend of rising deficits in commercial services. In addition, the country's income balance has improved significantly in the 2000s, reflecting developments in the international investment position (IIP) to be discussed shortly, and is now about one-quarter the size of Germany's merchandise trade surplus and much exceeds Germany’s net transfers. 


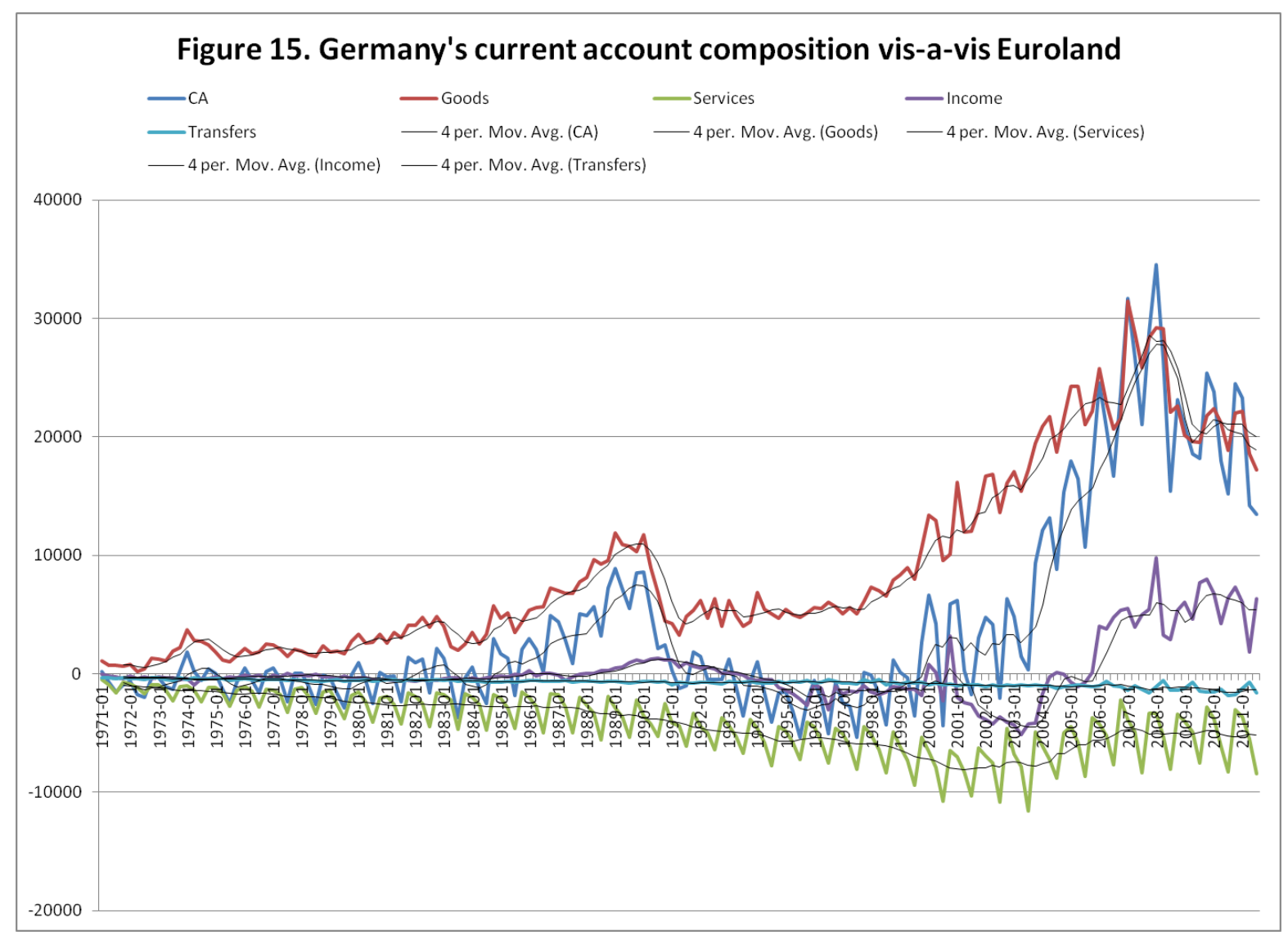

While the European crisis is hurting Germany through direct regionally-concentrated export exposures, the crisis is also benefiting the country in two important ways: first, by depressing the euro and hence stimulating non-euro net exports; and, second, by depressing German interest rates - owing to the market convention of Germany as a safe haven. While the latter channel has contributed to more balanced growth of the German economy than ever seen in the last decade, with net exports contributing “only” a third of GDP growth since 2010, ignoring Germany's vulnerability to its European partners through financial exposures may not suit the markets forever.

\section{GERMANY'S VULNERABILITY: DENIAL OF GERMANY'S EURO TRILEMMA CANNOT LAST}

For the past two years, stellar German GDP growth and a fast-improving government budget have much impressed the markets. With repeated bouts of panic engulfing the markets about the prospects of peripheral Euroland members, capital flight has awarded Germany record low 
interest rates. Germany's safe haven status in the markets' current perception arises from a historical record featuring Bundesbank discipline as guarantor of deutschmark stability and fiscal solidity in pre-euro times. But Europe's common market - and much more so- the common currency have tied Germany's fiscal fate to Europe in more intricate ways than currently appreciated by the markets. Specifically, the build-up of intra-area imbalances in competitiveness and current account positions has created corresponding financial exposures that are ultimately fiscal exposures of enormous proportion.

In section 2 above we illustrated that Euroland's overall current account position has been roughly balanced since the euro's inception while large and persistent intra-area imbalances have built up. Wolf's (2012) remark about Euroland being at war with double-entry bookkeeping was made in the context of discussing a recent European Commission report related to new EU regulation on the prevention and correction of "macro-economic imbalances" (see European Commission 2012). ${ }^{6}$ In addition to stating the obvious point that intra-area rebalancing will have to involve both surplus and deficit countries alike, it may be worthwhile to spell out some further national (and international) income accounting truths here, highlighting the vital issue of stockflow consistency in economic analysis as championed by the late Wynne Godley.

To begin with, a country that runs persistent current account surpluses, such as Germany, is thereby improving its net international investment position: either paying off (net) foreign debts or acquiring (net) foreign assets. Starting from near zero net foreign assets in the late 1990s, Germany's creditor position reached 40 percent of GDP by the end of 2010. Not only has Germany's net foreign asset position improved so markedly, the introduction of the euro has also seen a sharp rise in gross cross-border positions - reflecting surging gross capital flows of all kinds (FDI, portfolio equity, portfolio debt, and other investments, the latter including bank loans).

In principle, it is not necessary that Germany's rising gross and net foreign asset positions should include any significant direct exposures to deficit members that are among today's euro

\footnotetext{
${ }^{6}$ The Commission initially favored a symmetric treatment of current account surpluses and deficits in implementing the new "Macroeconomic Imbalances Procedure," which, however, met stark resistance from Germany and the ECB, holding stern views on deficits representing sinfulness while surpluses are really a sign of virtue. So the Commission's scoreboard on persistent current account imbalances came to feature an "indicative threshold" of 4 percent for deficits and an indicative threshold for surpluses of 6 percent. With Germany and the Netherlands just falling below the 6 percent threshold, I bite my tongue and forego any further comment on how much usefulness one might reasonably expect from this whole exercise.
} 
crisis countries. These countries might have borrowed from third-party (either member or nonmember) countries, while Germany might have invested in US Treasuries, for instance. However, while gross capital flows have grown sharply globally, and national balance sheets thus become more intertwined in the process across the globe, the degree of global financial integration is actually regionally concentrated and especially advanced within Euroland.

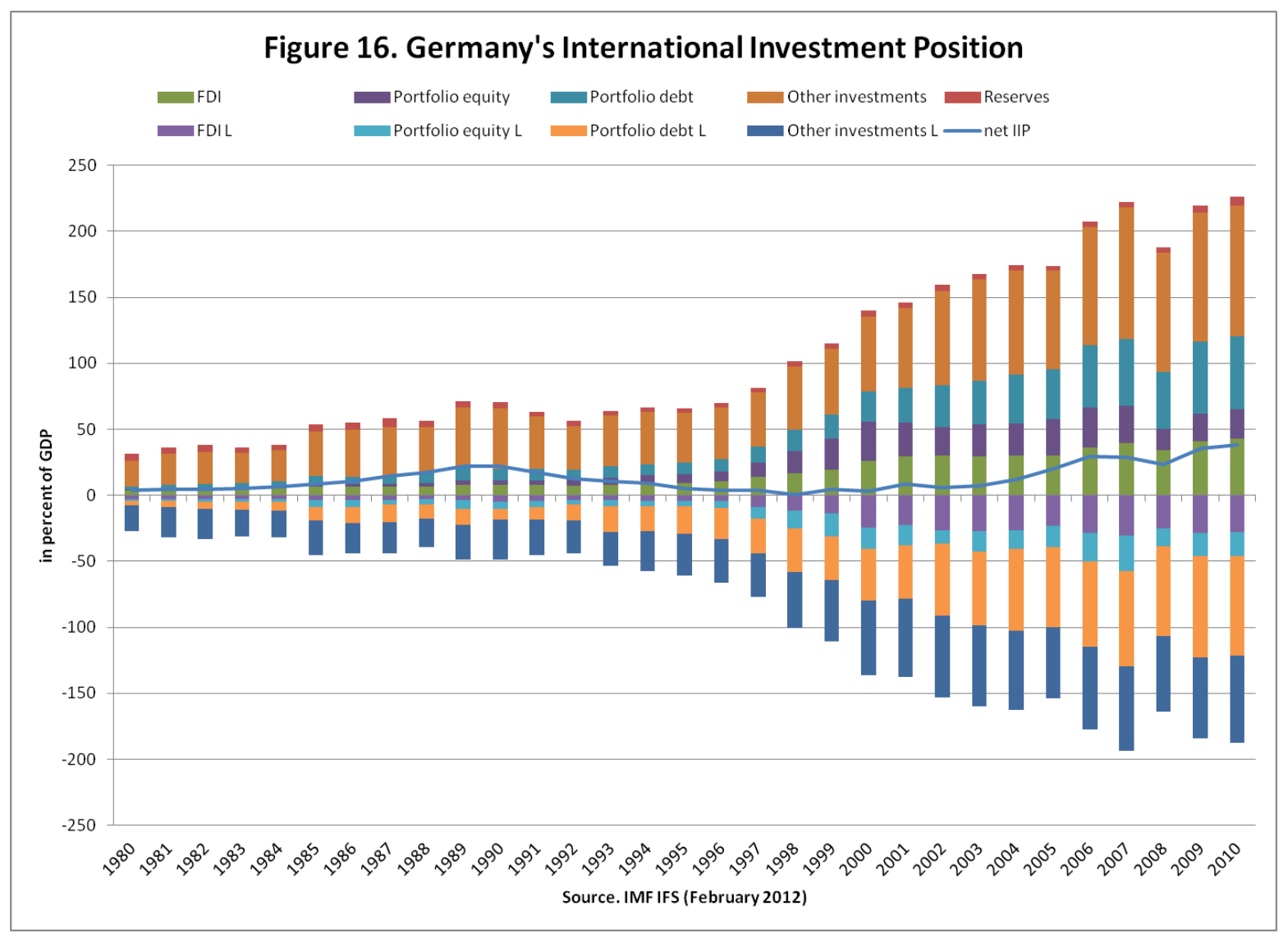

Discussing the developments and structure of Germany's international investment position since the beginning of EMU until the end of 2007, the German Bundesbank observes that a "decreasing home bias seems to have been offset by an increased euro-area bias" (Deutsche Bundesbank 2008: 25). At the beginning of the EMU, German investors' portfolio choices were still strongly biased toward domestic securities, and securities of other Euroland members were underrepresented compared to their share of the global market. In the following eight years, the Euroland shares in Germany's foreign assets and liabilities surged beyond the corresponding levels of trade integration. At the end of 2007, "Germany is therefore more financially integrated in the euro area than it is in a real economic sense," the Bundesbank (2008: 23) concluded. Referring to both loans as well as foreign securities holdings, the Bundesbank 
(2008: 18) also observed: “The banking sector plays a central role in Germany’s increasing financial integration with other countries. Almost half of all of Germany's external assets and liabilities ... were attributable to credit institutions at the end of 2007."

Both international "consolidated banking statistics," as compiled by the Bank for International Settlements (and related analyses such as Avdjiev, Upper, and Vause 2010), and an IMF study of "European financial linkages" (Waysand et al. 2010) constructing and analyzing a new database comprising bilateral external financial assets and liabilities confirm that Germany's global financial integration is especially concentrated within Euroland. And it is through these heightened financial exposures that Germany's overall vulnerabilities to euro crisis countries and the euro's fate arises.

It turns out that "Germany exhibited more similarity than most other countries between trade and financial links" (Waysand et al. 2010: 17). In particular, at the end of 2008, Germany's bilateral net IIPs within Euroland showed large creditor positions vis-à-vis Spain (7.5 percent of German GDP) and Italy (3 percent of GDP), almost exclusively in the form of portfolio debt and other investments. In addition, there is a large creditor position concentrated in other investments vis-à-vis the United Kingdom (6 percent of GDP), reflecting London's role as an international banking center, with the UK itself showing large bilateral IIP creditor positions in other investments vis-à-vis Spain, Italy, and France.

Germany’s bilateral IIPs vis-à-vis Ireland and France were atypical from a German perspective. While actually running trade deficits with Ireland, Germany has nonetheless built up a large creditor position vis-à-vis the euro crisis country, with a bilateral net IIP of 5 percent of GDP concentrated in portfolio debt and especially other investments. In France's case, while running up rising bilateral trade surpluses with France, Germany's overall bilateral IIP with its key Euroland partner is actually negative (4 percent of GDP). This, however, includes a creditor position in the other investment category (1 percent of GDP), which most likely is a reflection of the very active foreign business expansion of French banks, both within Europe and globally. It is noteworthy that France's overall net IIP has seen a shift from around positive 10 percent of GDP in the late 1990s to negative 10 percent by 2010. Yet, France, too, has large bilateral net creditor IIPs vis-à-vis Italy and Spain, concentrated in portfolio debt and other investments.

While it is clear from the IMF study that Germany is highly vulnerable to debt problems in the financially deeply integrated EU and Euroland, be it through direct exposures to Euroland 
crisis countries (Spain, Ireland, and Italy) or through indirect debt exposures via France and the United Kingdom (and to a lesser extent Luxembourg), it is worthwhile to highlight that these risks get crystallized in peculiar ways inside Europe's EMU today, namely on the balance sheet of the Eurosystem.

Quarterly data shows the surge in Germany's net IIP to 40 percent of GDP at its peak at the end of 2010, declining to 33 percent by the end of the third quarter of 2011 owing to negative valuation effects. While Germany's net debtor position in portfolio debt largely reflects the role of bonds as reserve assets, the rise in Germany's positive net foreign direct investment (FDI) position offset the decline in its positive net portfolio equity position. Of greatest interest is the category "other investments," decomposed here by sector (banks, nonbanks, government, and monetary authority, i.e. Bundesbank). The stark fact is that, after increasing fivefold from 5 percent of GDP in 2004 to 25 percent by the end of 2008, German banks' overall net creditor position has declined again to below 15 percent of GDP of late. Yet, while German banks are cutting back fast on their international exposures, concentrated in Europe, the Bundesbank's net foreign asset position has soared in their stead, largely taking the form of a surge in the German central bank's creditor position within the Eurosystem, as reflected in rising Trans-European Automated Real time Gross settlement Express Transfer system (TARGET2) imbalances. 


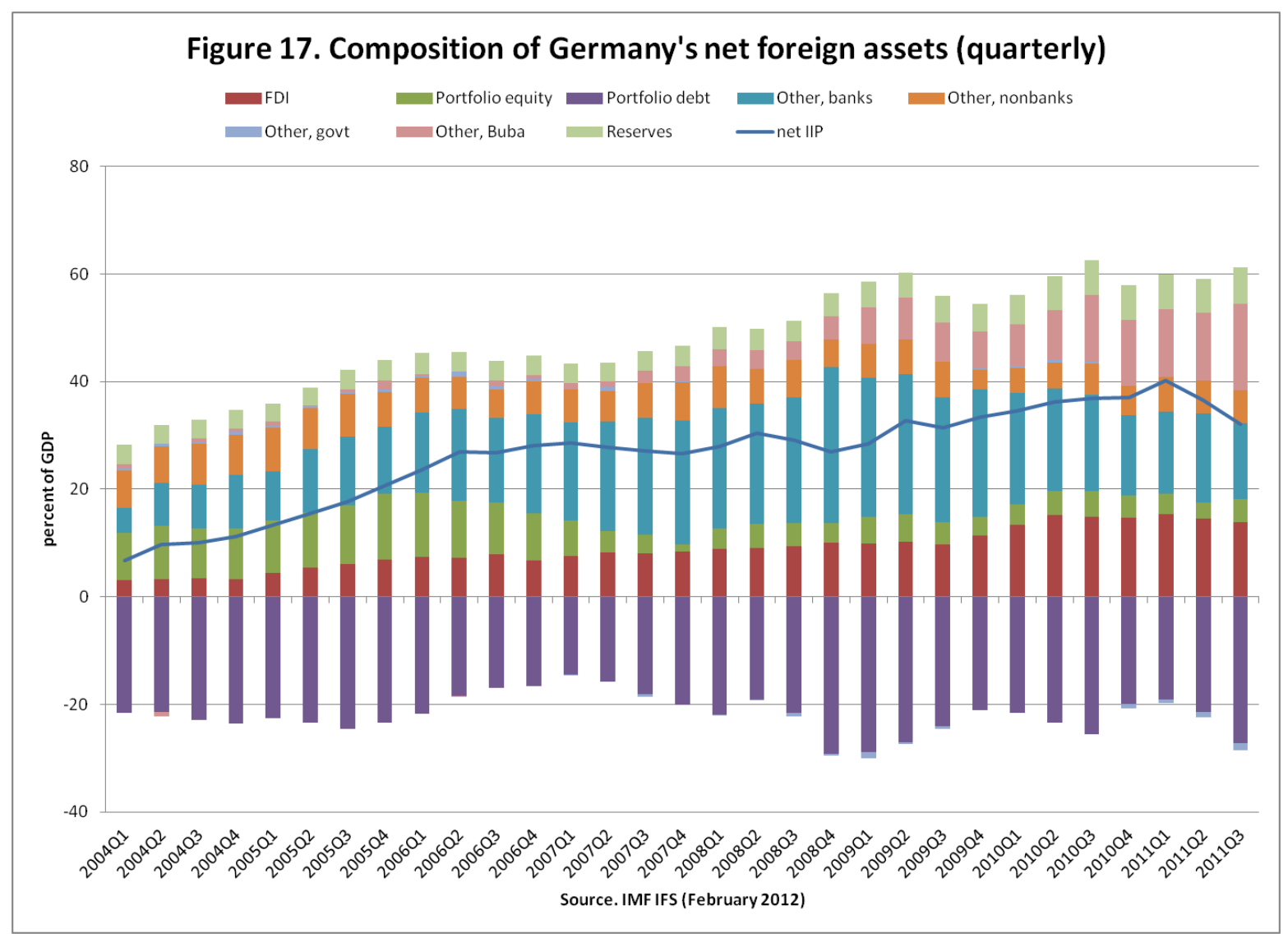

By linking wholesale payment systems and money markets across Euroland, TARGET2 is a core part of the technical infrastructure underpinning the euro, providing for final settlement on the Eurosystem's balance sheet. TARGET2 is essential to the implementation of area-wide monetary policy and interbank refinancing activities. TARGET2 balances arise endogenously when EMU members' balance of payments are not otherwise balanced over a certain period. It may be odd to think of flows of (foreign exchange) "reserves" inside a currency union, especially since TARGET2 balances are obviously denominated in euro. But the buildup of Germany's TARGET2 creditor balance is essentially the equivalent of "gold reserves" fleeing from elsewhere in the system toward the supposed safe haven Germany-only that those "gold reserves" are not exactly consisting of gold, but are more in the nature of overdraft loans made by the creditor central bank to the ECB.

The size of the Bundesbank's TARGET2 balances reached roughly one half of Germany's net international investment position by the end of the third quarter of 2011 (and have continued their rapid growth since) — much to the alarm of Hans-Werner Sinn, one of Germany's most vocal economists, and the Bundesbank, with a corresponding rise in anxieties 
among the German media and general public. While Sinn (2011a,b) recommends placing tight national caps on TARGET2 balances and requiring annual settlements of balances among member central banks by transfer of gold or foreign exchange reserves, the Bundesbank is directing its critique at the ECB's "Long-Term Refinancing Operations" (LTRO) of December 2011 and February 2012, since "[n] either providing life support to ailing banks nor propping up the solvency of sovereigns falls under the remit of monetary policy" (Weidmann 2012b; see also Wilson 2012). Both kinds of critiques or proposals are much beside the point.

It is obviously true that TARGET2 balances could not arise without Eurosystem lending (see Bindseil and König 2011). It does not follow that restricting either TARGET2 balances or Eurosystem lending, if workable at all, would make resolving the euro debt crisis any more likely. At issue is a twin banking and balance of payments crisis, the underlying causes of which were analyzed above. It is one thing that, going forward, continued competitiveness and current account imbalances presuppose continued financing (flows) for as long as they persist. It is quite another that the debt-overhang legacies (stocks) accumulated up until now need to be rolled over while regional financial integration may go into reverse and capital flight adds further vengeance to the plight. While the so-called "bailouts" of Greece, Ireland, and Portugal through the European Financial Stability Facility (EFSF) may have provided the respective sovereigns some breathing space, developments on the Eurosystem's balance sheet largely reflect the broader issue of financial disintegration and capital flight, featuring the freezing of bank refinancing through standard euro money market channels.

But the fate of sovereigns and banks in EMU member countries in a balance of payments crisis is closely intertwined: fiscally challenged sovereigns are constrained in supporting their commercial banks, while banks facing solvency and liquidity challenges are constrained in supporting their sovereigns. Any deterioration in one party's rating pulls down the other's, too. In Europe's EMU, both are missing the support of a national central bank in full control of national currency issuance. ${ }^{7}$ As a result, it is left for the Eurosystem to substitute for frozen interbank refinancing channels, either through nationally targeted "Emergency Liquidity Assistance" (see Whittaker 2011) or through system-wide liquidity measures (such as LTROs). Proposals to limit the role of ECB liquidity support and/or target balances would need to explain

\footnotetext{
${ }^{7}$ Contrasting the chartalist approach with mainstream optimum currency area theory, Goodhart (1998) had clearly identified these issues prior to the euro's launch.
} 
how default of banks and sovereigns in crisis member countries could be avoided without it. Such proposals seem to be especially popular in Germany, reflecting denial of what I elsewhere dubbed "Germany's euro trilemma."

Germany's euro trilemma is that Germany "cannot have all three: perpetual export surpluses, a no transfer/no bailout monetary union, and a "clean" independent central bank" (Bibow 2012a). While trade imbalances may persist for quite some time, at some point the prospect of bankrupting the debtor countries will no longer escape the markets' attention - at which time private financing will suddenly stop (or reverse). Trade imbalances may then be sustained by official lending, but such emergency loans (liquidity "bailouts") do not solve the underlying solvency problem — calling for debt forgiveness (proper fiscal bailouts). Therefore, as a rule, perpetual export surpluses, as apparently aspired by Germany, can only be sustained if offset by fiscal transfers. In fact, replacing lending by transfers, fiscal union proper could save and make the euro overnight.

Germany eagerly designed the Maastricht regime so as to exclude both transfers and bailouts of partners, but ignored that running perpetual trade surpluses would bankrupt its trade partners and thus make application of the forbidden medicine inevitable. The true choice facing Germany is to either bail out its bankrupt EMU partners or its own banks (after the latter got hit by EMU partners' defaulting on their debts).

Procrastinating on this simple choice has brought the Eurosystem into play. Of course, Germany also eagerly designed the Maastricht regime so as to shield the central bank system from public debt in order to protect its glorified independence. However, given the intertwined fate of sovereigns and national banks in Europe's EMU, not helping debtor sovereigns means worsening the troubles of debtor country banks. Accepting its de facto role as lender-of-lastresort to banking systems (rather than individual banks) through emergency liquidity provision in money markets, the ECB has watched euro interbank funding markets migrate onto the Eurosystem's own balance sheet. Just as in the case of EFSF "bailouts" or sovereigns, ECB emergency lending - at extended maturities and on the basis of lightened collateral requirements - does not make the underlying solvency problems go away either. As creditor country banks are given time to pull out and capital flight turns rampant, Germany's ultimate choice is merely being transformed into bailing out the Bundesbank instead of German banks. 
In short, Germany is on the hook and there is no way around it. ${ }^{8}$ Debt overhangs could be more easily worked off if intra-area competitiveness positions were restored without undermining growth. Alas, in continued denial of the country's euro trilemma, Germany also has her own views on how best to sustain growth while maintaining German (über-) “competitiveness" (i.e., export surpluses).

\section{UNCONDITIONAL AUSTERITY AND EUROLAND AS THE "SICK MAN OF THE WORLD ECONOMY"}

Offering his views on "rebalancing Europe," Bundesbank president Weidmann (2012c) observes that

normally, exchange rate movements are an important channel through which unsustainable current account positions are corrected - eventually, deficit countries devalue, while surplus countries revalue their currencies. The reaction this triggers in imports and exports then helps to bring the current account closer to balance.

Note that Weidmann describes adjustment for both deficit and surplus countries as being rather symmetric in this case. However, given that exchange rate "realignment" is no longer an option in a monetary union, adjustment will have to work through prices, wages, employment, and output, instead, which for Weidmann raises the question: which countries have to adjust? $\mathrm{He}$ offers a curiously asymmetric answer to this question:

The typical German position could be described as follows: the deficit countries must adjust. They must address their structural problems. They must reduce domestic demand. They must become more competitive and they must increase their exports. (Weidmann 2012c)

His "typical German answer" has some rather critical implications.

What may perhaps be the market consensus view suggests that, while deficit countries will have to go through an "internal devaluation" to restore their competitiveness, Germany

\footnotetext{
${ }^{8}$ The Bundesbank's (2012) Annual Report of 2011 makes the point that any losses arising from TARGET2 balances would be shared within the Eurosystem according to partner central banks' capital shares in the ECB, 27 percent in Germany's case. Confirming this view, Weidmann (2012b) also states, “As I see it, the Bundesbank's TARGET2 claims do not constitute a risk in themselves because I believe the idea that monetary union may fall apart is quite absurd." This hypothesis presumes that either exit or default of any one member would not trigger a domino effect that sees the Bundesbank as the last man standing — as playing out in sovereign debt markets with bonds.
} 
would experience the opposite form of "internal revaluation" through elevated inflation; with Euroland "meeting in the middle," as indicated in Figure 18 by symmetric convergence towards the two percent price stability norm that EMU members originally committed to. For instance, a Goldman Sachs study on the "price adjustment required for external sustainability" estimates that, while Ireland is already on target (or even slightly below), Portugal still needs to engineer a real depreciation of 35 percent, Greece around 30 percent, Spain and France around 20 percent, and Italy around 10-15 percent. The same study observes that: "the flipside of a required depreciation in the periphery is a required appreciation in Germany [of] close to 25 percent" (Nielsen 2012: 2), which is supposed to be brought about by above-trend output growth driving inflation well above 2 percent for a sustained period of time (more than 4 percent for five to ten years in their simulation).

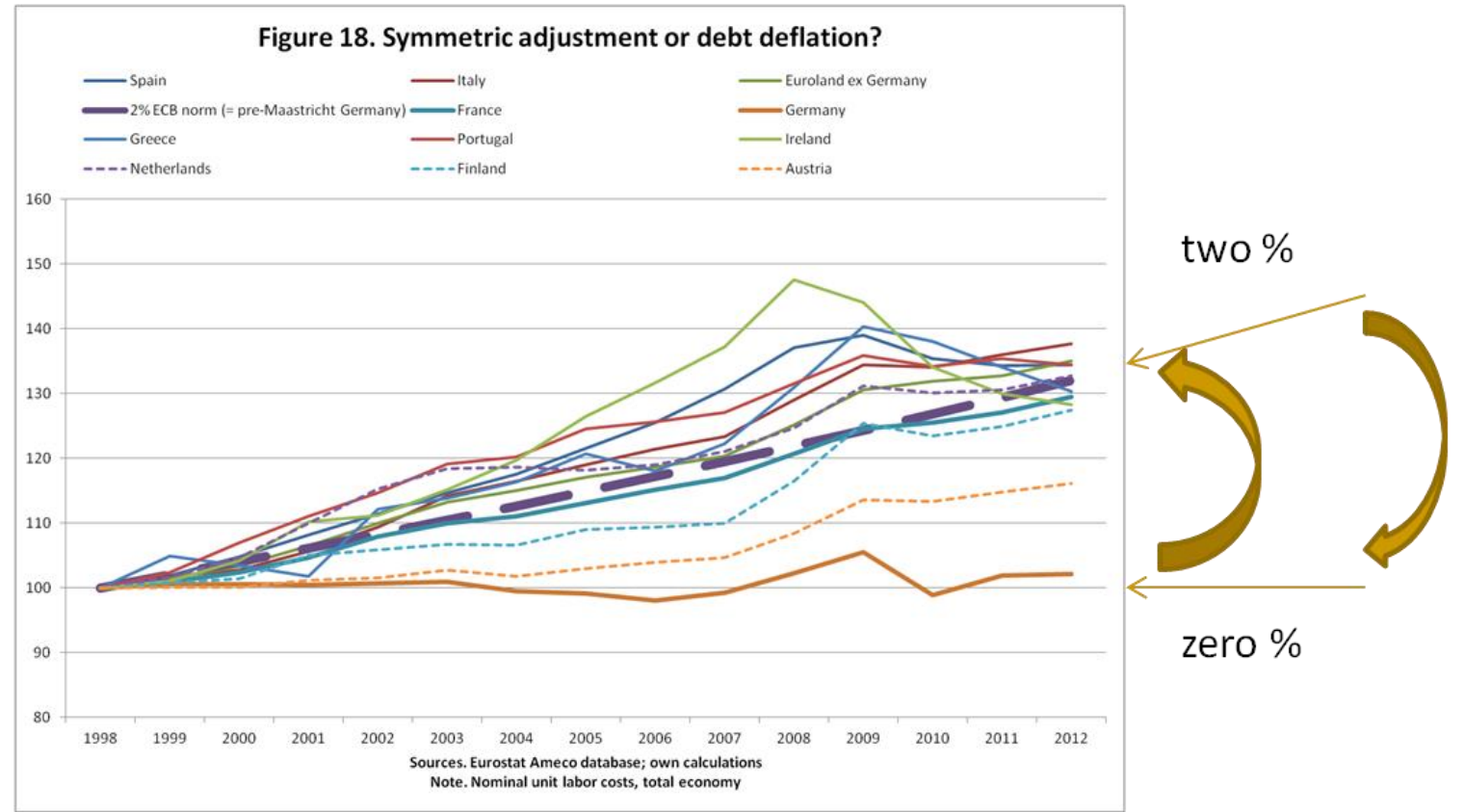

Rest assured that the "meeting in the middle" option is not on the table. From a German perspective, this adjustment path amounts to deliberately making Germany less competitive (although this would be the obvious result in case of exchange rate realignment, too, albeit with disinflationary effects in Germany). In case of internal price-wage adjustments, symmetry is not tolerable to Weidmann (2012c), asking: "how can Europe succeed in this world if we willingly give up our hard-won competitiveness?" ${ }^{\text {"I }}$ is clear, then, that Germany intends to stay the

\footnotetext{
${ }^{9}$ Recall here that wage repression rather than engineering ingenuity were behind Germany's "hard-won competitiveness" in the first place.
} 
course and force everyone else to converge to its new zero percent stability norm instead. If this means forcing Euroland (ex-Germany) on a debt deflation course, as it does, so be it. Actually, not at all fearsome of deflation, Weidmann (2012c) even acknowledges that "unless productivity growth increases miraculously, it is certainly true that prices and wages will have to fall in many cases [but erroneously asserts that] we must not confuse such a one-time adjustment with fullfledged deflation."

It is, of course, Weidmann himself who is confusing a one-time adjustment with a debt deflation process. Germany's prescribed adjustment path is forcing even France, the country that stayed most loyal the 2-percent course that EMU partners had committed to, on a debt deflation course, joining Italy, the other large EMU member already imposing brutal austerity. As EMU contraction is bound to catch up with Germany at some point, the country's constitutional "debt brake" will then seal EMU-wide austerity-driven debt deflation. Assuming that the ECB may have both the power and the will to prevent a full-blown debt deflation is anything but a safe bet-especially as the Bundesbank will also continue to do her utmost to prevent aggressive monetary action.

Weidmann's speech contains further eye-opening observations that are of great interest to the global community. Weidmann is not oblivious to the fact that "surplus countries will eventually be affected as deficit countries adjust. ... As the deficit countries import less and become more competitive, surplus countries will run lower surpluses.” Note here, however, that he expects Germany to "eventually" run "lower" surpluses, not a balanced trade account. For Weidmann, earlier in his speech, made the point that "a large proportion of the current account deficits and surpluses result from trade with countries outside the euro area." In fact, as the analysis in section 5 above has revealed, the squeezing of Germany's intra-area trade surpluses through austerity measures in EMU partner countries is receiving some welcome offset since the austerity-wreckage in EMU partners is conveniently depressing the euro, so as to stimulate Germany's extra-area exports. As other EMU partners "restore their competitiveness" and realign theirs with Germany's competitiveness for intra-area rebalancing, they would see their extra-area competitiveness improve accordingly, too. It is thus of great interest that Weidmann (2012a) describes the improvement in Germany's current account balance since the start of EMU as the result of "restoring" Germany's competitiveness. Arguably, if turning a nearly balanced current account into an 8 percent of GDP surplus qualifies as "restoring" competitiveness, 
Weidmann reveals to the world community what the true implications of a German-led EMU really are: supercharged mercantilism.

Containing the threat posed by the self-inflicted Euroland crisis to the global recovery, therefore, has to focus on stemming euro weakening. Mindless austerity imposed continent-wide under German leadership - following the example of Germany's constitutional "debt brake," which inspired the latest "strengthening" of the SGP as well as the new "fiscal compact"-is suffocating domestic demand. As ever, the EU's "growth strategy" is just doing "more of the same," that is, more - allegedly, confidence-boosting - austerity and structural reform, amounting to nothing but an anti-growth strategy. ${ }^{10}$ Adding a growth crisis to Euroland's twin banking-and-balance-of-payments crisis is bound to make solvency problems worse, not better, and turn Europe into an even bigger drag on global growth and a bigger risk to global stability. A euro breakup is a non-negligible risk at this point since timely political agreement may not be forthcoming and ECB liquidity proves unconvincing at some point.

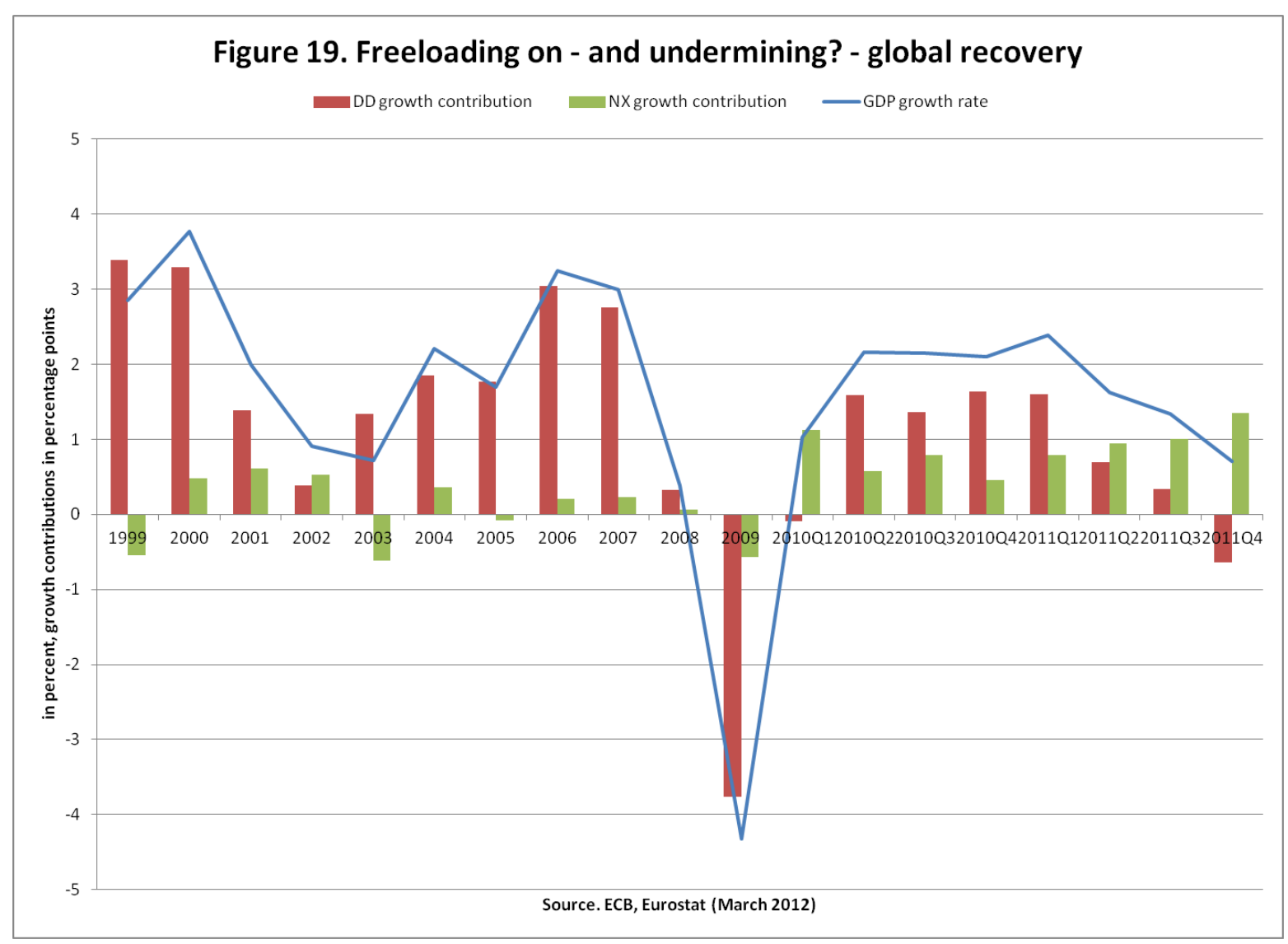

\footnotetext{
${ }^{10}$ Varoufakis and Holland (2011) provide a constructive "modest proposal" for overcoming the euro crisis, including a proper growth strategy.
} 
From a global perspective, not only is Euroland shamelessly freeloading on external growth to offset suffocation of domestic demand through mindless area-wide austerity (see Figure 19), but adding insult to injury, Euroland is also hijacking the IMF as global sponsor in backstopping the EFSF/ESM (European Stability Mechanism) "firewall" for its purely homemade internal crisis. German mercantilism had given rise to regional imbalances and global tensions in the pre-EMU past. The euro has multiplied Germany's weight - and the gravity of German policy views - in the global economy. Effectively, Germany, the world champion of moral hazard talk, is holding the world community hostage to a "too big to fail" global risk "made in Germany" today: arising as the potentially lethal mix of a dysfunctional monetary union paired with the economic consequences of Germany's denial of her euro trilemma. It is one thing that, by freeloading on external growth, Euroland is reneging on its commitments to the G-20 process of global rebalancing. It is quite another for Euroland to create the world's foremost threat to stability by self-inflicted folly and to not even be ashamed of "marshalling support from countries that are either more fiscally challenged or a lot poorer than the eurozone itself" to bail it out (Bibow 2012b).

\section{CONCLUDING REMARKS}

Critical flaws in the design of the Maastricht regime together with regime-antagonistic policies pursued by the monetary union's largest member, Germany, have brought the current homemade crisis upon Euroland. The crisis is best understood as a twin banking and balance-of-payments crisis. The required resolution calls for bank recapitalization and symmetric internal rebalancing, both of which can only be achieved if growth is sustained alongside. In a large economy such as Euroland, that means sustaining domestic demand growth. By erroneously treating the situation as a "sovereign debt crisis," calling for nothing but austerity and wage deflation in debtor countries, Euroland is adding a self-inflicted growth crisis on top of its predicament, which will backfire by further aggravating the underlying twin-crisis. Turning Euroland into the "sick man of the world economy" creates a global "too big too fail" threat and corresponding moral hazard that is challenging the global community to the utmost.

Germany's ill-guided views and conduct have burdened EMU with imbalances and debt legacies that will be very difficult to overcome without reforming EMU in the direction of a full- 
blown fiscal union (Bibow 2010). A fiscal union can take many different forms. Apart from covering the Common Agricultural Policy, the current EU budget of roughly 1 percent of EU GDP allows for some redistribution among members to foster catching-up and cohesion. As the budget has to be balanced, it cannot serve stabilization policy purposes. Goodhart (2007) recalls two reports by the European Commission examining the minimum requirements of federal fiscal support of a common currency. While the first, the so-called MacDougall Report of 1977, argued that a federal budget of 5 to 7 percent of EMU GDP would be necessary, the latter report of 1993, titled "Stable Money, Sound Finance," found that even at a much smaller annual cost of just 0.2 percent of EMU GDP, a stabilization mechanism for asymmetric shocks comparable to what exists in the US could be established. This minimalist "mutual insurance" version of a fiscal union would still leave it to national fiscal policies to coordinate an appropriate union-wide fiscal stance to counter symmetric shocks.

The "no bailout" clause of the Maastricht Treaty denies any role for mutual insurance, while the ill-named SGP has never even attempted to establish proper coordination of fiscal stance. Further crimping members' scope for flexibility in dealing with asymmetric shocks, the newly strengthened SGP cum "fiscal compact" once again utterly fail in filling the vital EMU policy vacuum of a missing growth strategy — which must include domestic demand management!

Perhaps the greatest irony of a "euro (crisis) made in Germany" is that failure to prevent asymmetric shocks potentially arising from wage divergences, amounting to nothing else but following through the original thrust of monetary cooperation in Europe directed at forestalling competitive devaluations, has much increased the required scope for fiscal union in ensuring the euro's future survival. There is a non-negligible risk that the political process may not produce timely decisions before ECB liquidity runs dry. 


\section{REFERENCES}

Almunia, J. 2008. “Foreword.” In EMU@10-Successes and Challenges after Ten Years of Economic and Monetary Union. Brussels: European Commission.

Avdjiev, S., C. Upper, and N. Vause. 2010. "Highlights of International Banking and Financial Market Activity. BIS Quarterly Review, December: 13-25.

Baba, N., R.N. McCauley, and S. Ramaswamy. 2009. "U.S. Dollar Money Market Funds and Non-U.S. Banks.” BIS Quarterly Review, March: 65-81.

Benoit, B. 2009. "Germany Ready to Help Eurozone Members.” FT.com, February 18.

Bibow, J. 2001. "Making EMU Work: Some Lessons from the 1990s." International Review of Applied Economics 15(3): 233-259.

- 2003. “On the ‘burden' of German unification.” Banca Nazionale del Lavoro Quarterly Review 61(225): 137-169. [Originally publishes as Working Paper No. 328. Annandaleon-Hudson, NY: Levy Economics Institute of Bard College.]

_ 2004. "Assessing the ECB's Performance Since the Global Slowdown-A Structural Policy Bias Coming Home to Roost?” Working Paper No. 409. Annandale-on-Hudson, NY: Levy Economics Institute of Bard College.

_ 2005. "Issing Fails to Justify Claims That ECB Policy Flagged Up Likely Threats." Letter to the Editor, Financial Times, December 19.

_ 2006a. "Inflation Persistence and Tax-Push Inflation in Germany and the Euro Area: A Symptom of Macroeconomic Mismanagement?” Studies 1/2006. Düsseldorf, Germany: Institut fuer Makrooekonomie und Konjunkturforschung (IMK).

_ 2006b. "The Euro Area Drifting Apart-Does Reform of Labor Markets Deliver Competitive Stability or Competitive Divergence?" In Structural Reforms and MacroEconomic Policy. ETUC, 76-86. 
- 2007a. "How the Maastricht Regime Fosters Divergence as Well as Fragility." In P. Arestis, E. Hein, and E. Le Heron (eds.), Monetary Policies-Modern Approaches. Basingstoke, UK: Palgrave. [Originally published as Working Paper 460. Annandale-onHudson, NY: The Levy Economics Institute of Bard College.]

_ 2007b. "Global Imbalances, Bretton Woods II, and Euroland's Role in All This." In J. Bibow and A. Terzi (eds.) Euroland and the World Economy-Global Player or Global Drag? Basingstoke, UK: Palgrave. [Originally published as Working Paper 486.

Annandale-on-Hudson, NY: The Levy Economics Institute of Bard College].

_ 2009a. "The Euro and Its Guardian of Stability: The Fiction and Reality of the 10th Anniversary Blast.” Working Paper no. 583. Annandale-on-Hudson, NY: The Levy Economics Institute of Bard College. Forthcoming in L.-P. Rochone (ed.), Monetary Policy and Crisis, Cheltenham, UK: Edward Elgar.

-2009b. Keynes on Monetary Policy, Finance and Uncertainty: Liquidity Preference Theory and the Global Financial Crisis. London, UK and New York, NY: Routledge.

—. 2010. "Suffocating Europe." Eurointelligence, June 25.

_ 2012a. "To Make or Break the Euro: Germany's Euro Trilemma." Eurointelligence, February 24.

_.2012b. "Deal Is Indeed Unacceptable." Financial Times, Letter to the editors, April 4.

Bindseil, U. and P.J. Koenig. 2011. "The Economics of TARGET2 Balances." SFB Discussion Paper 2011-035.

Borio, C. and P. Disyatat. 2011. Global Imbalances and the Financial Crisis: Link or No link?" BIS Working Paper No. 346, May.

Deutsche Bundesbank. 2008. "Monthly Bulletin, Germany's International Investment Position Since the Beginning of Monetary Union: Developments and Structure." October, pp. 1532. 
—. 2012. "Annual Report 2011, TARGET2 Balances in the Eurosystem." pp. 48-50.

European Central Bank (ECB). 2005. "Asset Price Bubbles and Monetary Policy.” Monthly Bulletin April: 47-60

European Commission. 2012. Report from the Commission, Alert Mechanism Report, Report prepared in accordance with Articles 3 and 4 of the Regulation on the Prevention and Correction of Macro-Economic Imbalances, Brussels, 14 February, http://ec.europa.eu/economy_finance/economic_governance/documents/alert_mechanism report_2012_en.pdf

Flassbeck, H. 2007. "Wage Divergences in Euroland: Explosive in the Making." In J. Bibow and A. Terzi (eds.) Euroland and the World Economy: Global Player or Global Drag? London, UK: Palgrave-Macmillan: 43-52.

Goodhart, C.A.E. 1998. "The Two Concepts of Money: Implications for the Analysis of Optimal Currency Areas." European Journal of Political Economy 14 (3): 407-432.

- 2007. "Replacing the Stability and Growth Pact?" In J. Bibow and A. Terzi (eds.) Euroland and the World Economy: Global Player or Global Drag? London, UK: Palgrave-Macmillan: 135-153.

G-20 Leaders. 2009. “The Leaders Statement: The Pittsburgh Summit.” 24-25 September.

Issing, O. 2005. "One Size Fits All! A single Monetary Policy for the Euro Area." Speech given in Frankfurt, Germany, 20 May. http://www.ecb.int/press/key/date/2005/html/sp050520.en.html

McCauley, R.N., and G. von Peter. 2009. "The U.S. Dollar Shortage in Global Banking." Quarterly Review March. Basel, Switzerland: Bank for International Settlements.

McGuire, P., and G. von Peter. 2009. "The US Dollar Shortage in Global Banking and the International Policy Response.” BIS Working Paper No. 291, October.

Mundell, R.A. 1961. "A Theory of Optimum Currency Areas." American Economic Review 51(4): 657-675. 
Nielsen, L.H.W. 2012. "Achieving Fiscal and External Balance (Part 1): The Price Adjustment Required for External Sustainability.” European Economics Analyst No. 12/01, March 15, Goldman Sachs.

Parkin, B. 2010. “Merkel Seeks 'Decisive' German Cuts as Geithner Urges Spending.” Bloomberg, June 6.

Sinn, H.-W. 2011a. “The ECB's Secret Bailout Strategy.” Project Syndicate, April 29. http://www.project-syndicate.org/commentary/the-ecb-s-secret-bailout-strategy

—. 2011b. "The ECB's Stealth Bailout." www.vox.org, June 1. http://www.voxeu.org/index.php?q=node/6599

Trichet, J.-C. 2011. "Economic and Monetary Union-What We Have Achieved and What We Must Do Next." Speech, January 7.

Varoufakis, Y. and S. Holland. 2011. "A Modest Proposal for Overcoming the Euro Crisis.” Policy Note 2011/3, May. Annandale-on-Hudson, NY: Levy Economics Institute of Bard College.

Waysand, C., K. Ross, and J. de Guzman. 2010. "European Financial Linkages: A New Look at Imbalances.” IMF Working Paper WP/10/295.

Weidmann, J. 2012a. “Containing the Sovereign Debt Crisis-Germany's Role and Contribution.” Speech, Mexico City, February 24, BIS Central Bankers' Speeches. http://www.bis.org/review/r120228b.pdf

_. 2012b. "What Is the Origin and Meaning of TARGET2 Balances?" Deutsche Bundesbank, March 15. http://www.bundesbank.de/download/presse/publikationen/20120315.target2_balances.p $\underline{\mathrm{df}}$

_. 2012c. “Rebalancing Europe.” Speech, London, March 28, BIS Central Bankers' Speeches. http://www.bis.org/review/r120329a.pdf 
Whittaker, J. 2011. “Intra-Eurosystem Debts.” Lancaster University Management School, March 30.

Wilson, J. 2012. “Bundesbank Squares Up to Draghi’s ECB.” Financial Times, March 1. http://www.ft.com/intl/cms/s/0/eb335298-63be-11e1-8762-

$\underline{\text { 00144feabdc0.html\#axzz1oDRIDiQ5 }}$

Wolf, M. 2012. “The Pain in Spain Will Test the Euro.” Financial Times, March 6. http://www.ft.com/intl/cms/s/0/f54332d2-66dc-11e1-9e53$\underline{00144 f e a b d c 0 . h t m l \# a x z z 1 q y w y l c h O}$

United Nations Conference on Trade and Development (UNCTAD). 2010. Trade and Development Report. Report by the secretariat, New York \& Geneva. 